\title{
Women in business
}

\author{
By Peggy Causer and Neil Park, Office for National Statistics
}

\section{Abstract}

The role women have in business and the impact they have on regional economies is of increasing interest. This article looks at how to monitor trends among women who are active in business and how to understand the way they work and what drives them.

It's true to say information on the owners of businesses is limited and most is not broken down by sex. However regular data on self-employment for both women and men is available from the Labour Force Survey and this is often used as a proxy for business ownership. A high proportion of business ownership, around 90 per cent, is made up of the self-employed.

The number of women who are self-employed has grown in recent years, but in isolation, this could be misleading. Much of the growth is in women working part-time and among those focusing on more flexible working patterns to fit into domestic commitments. The southern regions of the UK have higher self-employment rates than elsewhere, but the difference between regions is far less if full-time self-employment only is included. Some women, who think of themselves as self-employed, may only work for very few hours - for example, less than six hours a week.

\section{Introduction}

Targets to increase the proportion of largely women-owned businesses from 15 per cent to 18 to 20 per cent by 2006 were set by the Government in 2003. This article explores various options for measuring female enterprise and their strengths and weaknesses.

The concepts of increasing female enterprise and business creation are embedded in each Regional Development Agencies' Regional Economic Strategy (RES). A Women's Enterprise Taskforce was created in November 2006 to drive forward this over-arching strategy.

In addition, there is considerable interest in wider issues relating to women in business and the relevant drivers. Women entrepreneurs are acknowledged to be effective in enhancing the economy generally, and there is evidence to suggest that women-owned businesses have a beneficial community impact through informal networking, particularly in rural areas'.

This article identifies the available data on women in business. It considers their suitability as indicators for monitoring female business activity and more generally for enhancing understanding of the wider issues relating to women in business. It focuses especially on the rich data on selfemployment available from the Labour Force Survey and Annual Population Survey.

\section{Indicators which are regularly used}

There are three main sources of data on female entrepreneurial activity

1. Members of the various Global Enterpriseship Monitor $(G E M)^{2}$ research consortia conduct international surveys every few years which provide an overview of entrepreneurial activity for both men and women. Consistent methodology is used by groups in each country so that the UK can be compared with other countries, but also indicators can be provided at a regional level. These surveys aim to explore the enterprise culture and include information on people's intentions as well as activity.

1 See Further information and Reference sections.

2 GEM is a number of international consortia, led in the UK by the London Business School. Surveys are conducted every few years to provide estimates of entrepreneurial activity across 42 countries. See Further information section at the end of this article. 
Figure 2.1 Regional differences in earlystage entrepreneurial activity, 2007
Figure 2.2 Rate of business births, 2002 and 2007

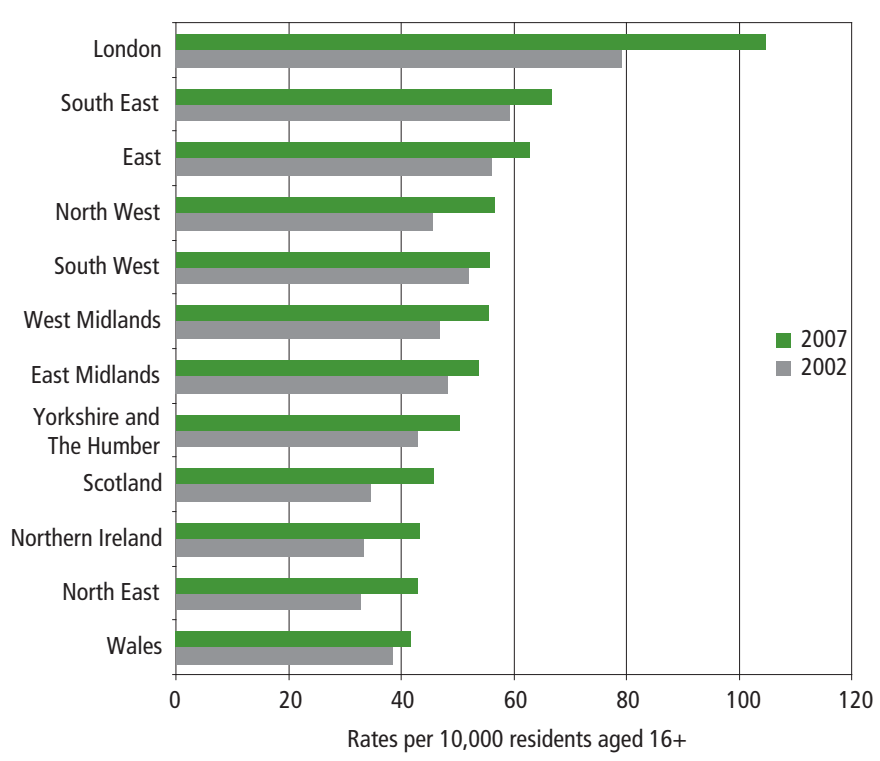

Source: Office for National Statistics

Of the new businesses created in 2007, at least 90 per cent in every region had four or less employees and 97 or 98 per cent had nine employees or fewer. Women are more likely to run businesses with few, or no, employees.

East, where about 9 per cent of men were engaged in 'early-stage entrepreneurial activity' in 2007, compared with less than half that figure for women. Total early-stage entrepreneurial activity (TEA) is defined as those adults who, on their own or with others, are currently trying to start a new business independent of their work, trying to start a new business as part of their work or are the owner or manager of a business. According to the GEM survey in 2007, Northern Ireland had the lowest proportion of women engaged in TEA, around 2 per cent of the adult population aged 18 to 64. It must be remembered that entrepreneurial activity identified by the survey does not necessarily translate to business ownership.

2. The number of businesses starting up in a region is another useful measure of entrepreneurial activity. Historically, the rate of businesses first registering for VAT relative to the number of adults in an area was quoted, but many small businesses fall below the VAT threshold, at least in their initial phases. A new series of 'business births', utilising a wider definition based on the VAT and PAYE registrations has been developed and the first data relating to 2007 were released in November 2008. Unfortunately, the data do not distinguish between business started by women or men, but rates of activity are useful contextual information and, as will be shown later (Figure 2.6), areas which have high rates of male entrepreneurial activity tend also to have high female rates. Figure 2.2 shows that the rate for creation of new businesses for 2002 and 2007 was highest in London with around 105 per 10,000 resident adults in 2007. However, this rate will be inflated by people establishing their business in London when they are resident elsewhere.
3. Self-employment is a major component of business ownership although, as will be shown later, there are a few different characteristics. People who are self-employed account for at least 90 per cent of business owners in each region. Estimates of self-employment are readily available, updated on a quarterly basis from the Labour Force Survey ${ }^{3}$ (LFS), and can therefore be used as a valuable indicator of business activity. However, there can be considerable variability in quarterly data and it is more appropriate to use annual data from the Annual Population Survey (APS) when considering sub-national analysis. The levels of business ownership are generally higher than the number of selfemployed, but trends in the two measures tend to follow similar patterns. Data on business ownership are also available from the LFS, but are collected much less frequently - only one quarter in every two years. The article first examines self-employed women in detail and then looks at the available data on business ownership from the LFS.

\section{Current trends in self-employment}

Self-employment, as measured by the LFS, is one of the most commonly used proxies for the level of business ownership. In common with other ONS surveys, the LFS is based on selfreported assessment. The employment status is assessed using a question which asks whether someone is working as an employee or is self-employed.

3 See Notes on sources section for further details relating to LFSIAPS. 
Figure 2.3 National self-employment, 2000 to 2008
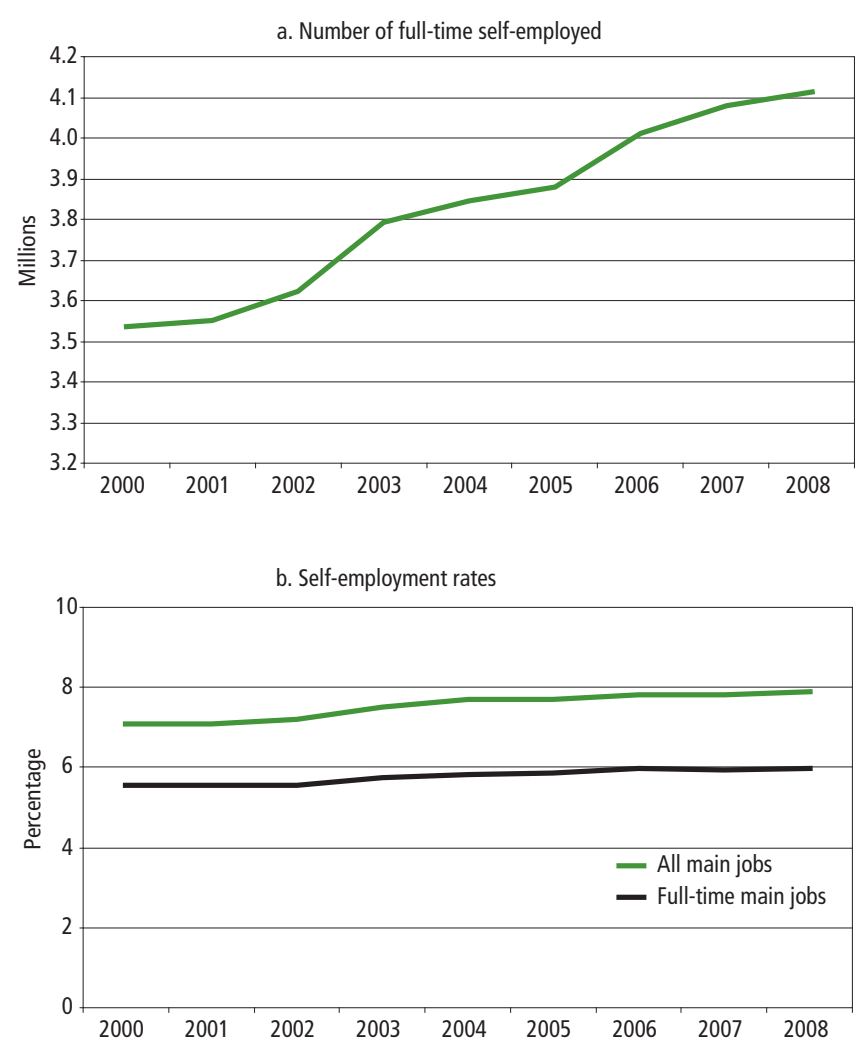

Notes:

Data for 2000 to 2003 are from the Local Labour Force Survey.

Data for 2004 to 2007 are from the January to December annual files.

Data for 2008 are from the July 2007 to June 2008 file.

See Notes on sources section.

In the above charts, self-employment rates are based on main job while the total number of self-employed jobs is the sum of both main and second jobs.

Source: Local Labour Force Survey/Annual Population Survey,

Office for National Statistics

The survey asks about the activities of each respondent in both their main and second jobs (should they have one), details of subsequent jobs or further economic activity are not collected. The vast majority of self-employed jobs are main jobs although there are significant numbers of self-employed second jobs and this has been increasing over the last few years. Second jobs are, of course, usually part-time. All surveys are subject to sampling variation and results shown in this article represent mid points of ranges of possible values. For further details on confidence intervals please see Table 2.25 in the Notes on sources section on page 49 . This variability means that comparisons between regions should be made with care.

\section{National and regional overview}

The total number of self-employed jobs in the UK rose by over half a million between 2000 and 2008 to reach around 4.1 million. Over the same period the national (UK) selfemployment rate ${ }^{4}$ has risen slightly from 7.1 per cent to 7.9 per cent when counting all main self-employed jobs.

4 Self-employment rate $=$ (number of self-employed/all those aged $16+) * 100$.
Table 2.4 Numbers self-employed' ${ }^{1}, 2000$ and 2008

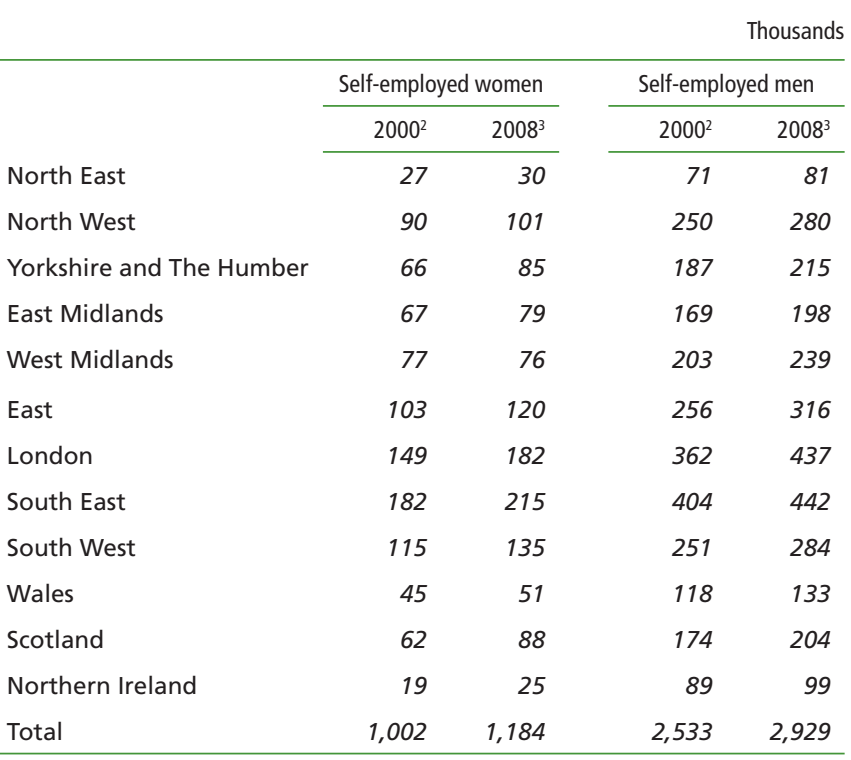

1 Self-employed in either main or second job.

22000 data is from the Local Labour Force Survey and relates to March 2000 to February 2001.

32008 data is from the July 2007 to June 2008 APS dataset.

\section{Source: Annual Population Survey}

If only full-time jobs are included the rate has grown from 5.5 per cent to just less than 6 per cent.

The number of self-employed people varies considerably between regions from 111,000 in the North East to nearly six times this number in the South East $(657,000)$ in 2008. Between 2000 and 2008 the number of women who were self-employed increased by 33,000 in London, but the highest percentage increase was in Scotland at over 40 per cent, which equated to an additional 25,000 self-employed women.

Increases in male self-employment were more modest during the same time period with only London and the East showing increases of 20 per cent or more. In many regions the overall numbers of self-employed men remained fairly constant over the eight year period, except in a few areas such as London, where there was an increase of 75,000, and the South East, East and Scotland, where there were smaller increases.

Figure 2.5 shows the self-employment rates for each of the regions and countries making up the UK from the latest Annual Population Survey (APS). It compares data for the 12 month periods July 2007 to June 2008, and March 2000 to February 2001. As can be seen, the self-employment rate for women is highest in the three southern regions of England - London, the South East and the South West - at around 6 per cent of the population aged over 16 in each area. The lowest selfemployment rate is in the North East at just below 3 per cent. [The lines at the top of each bar indicate the range of possible values (confidence interval of 95 per cent).]

The self-employment rate for women increased in most regions between 2000 and 2008 by an average of 0.5 percentage points. The rate in Scotland increased by about twice the 


\section{Figure 2.5 Comparison of regional self-employment ${ }^{1}$ rates for women}

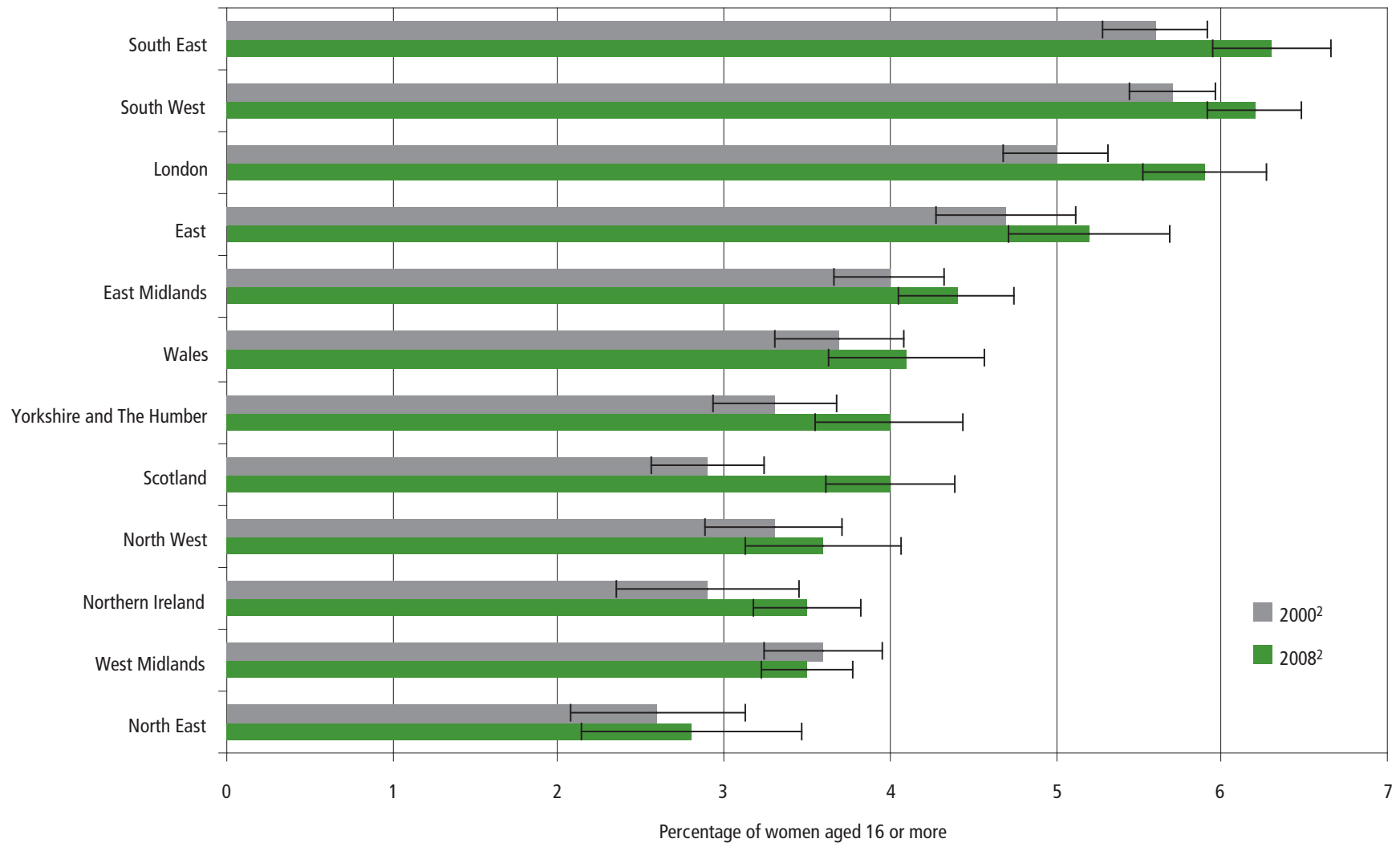

Note: The lines at the end of each bar indicate the range of possible values (95 per cent confidence interval).

1 Self-employed in either main or second job.

2 Data for the 12 month periods March 2000 to February 2001 and July 2007 to June 2008.

Source: Annual Population Survey/Local Labour Force Survey, Office for National Statistics

national average and was estimated to have reached 4 per cent in 2008, compared with a UK self-employment rate of 4.7 per cent. Increases over the eight year period in London, Yorkshire and The Humber, and the South East were also statistically significant, but for other areas the changes may be due to sampling variability.

Self-employment rates for men and women are closely correlated (see Figure 2.6). The highest self-employment rates for women are found in regions with the highest selfemployment rates for men. Conversely areas such as the North East have the lowest rates of self-employment for both sexes. There is one exception to this rule, Northern Ireland, which has the highest rate of self-employment for men and the second lowest rate for women.

\section{Full-time and part-time working}

Although the highest rates of overall female self-employment can be found in the three southern regions of the UK, this could be misleading in the context of business ownership or entrepreneurship. A considerable proportion of self-employed women in the South East and South West work part-time or are self-employed in their second job. In these two regions less than half the self-employed women worked full-time.
Figure 2.6 Relationship of self-employment rates $^{1}$ of men and women, July 2007 to June 2008

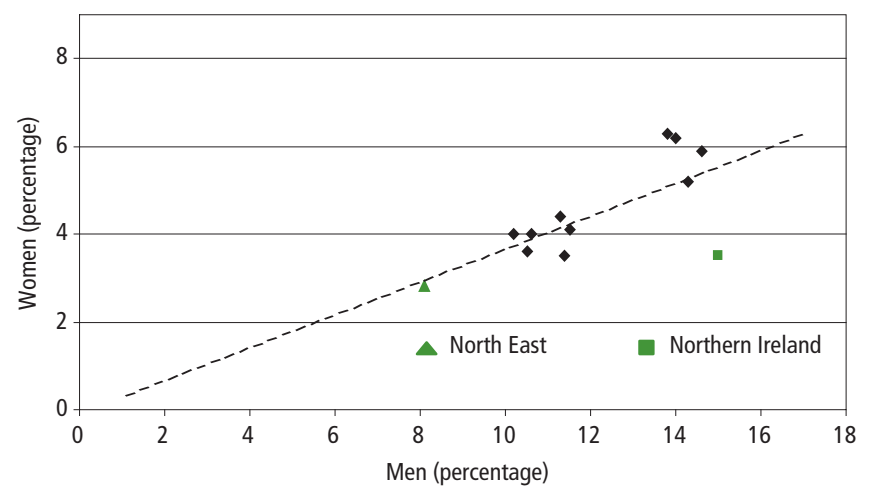

1 Self-employment in main or second job.

Source: Annual Population Survey, Office for National Statistics

As can be seen from Figure 2.7, the range of full-time selfemployed rates is much narrower than the overall rate. London has the highest proportion of women working as full-time selfemployed, almost 3 per cent. Although overall rates of selfemployment were lowest in the North East, West Midlands and 


\section{Figure 2.7 Components of women's self-employment', July 2007 to June 2008}

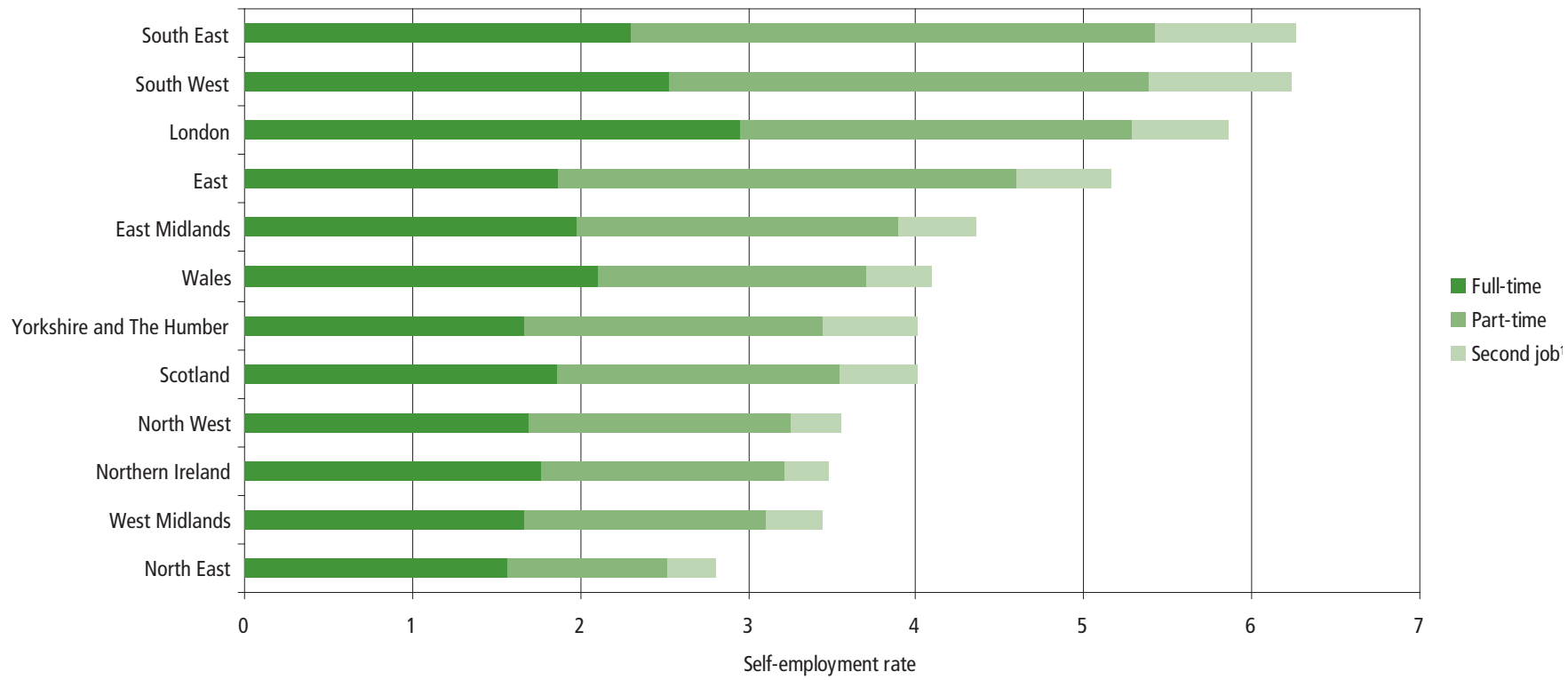

1 Self-employed in second job only.

Source: Annual Population Survey, Office for National Statistics

Northern Ireland, full-time rates in these areas are very similar to many of the other regions. With part-time rates, the range is wider from slightly less than 1 per cent in the North East to more than 3 per cent in the South East.

About 86 per cent of self-employed men in the UK work fulltime compared with just 50 per cent of women who are selfemployed (see Figure 2.8). In the East and South East the differences are more pronounced than elsewhere, with 86 per cent of self-employed men working full-time compared with just over 40 per cent of self-employed women. Differences are less marked in the North East where 62 per cent of

Figure 2.8 Proportion of self-employed ${ }^{1}$ working part-time, July 2007 to June 2008

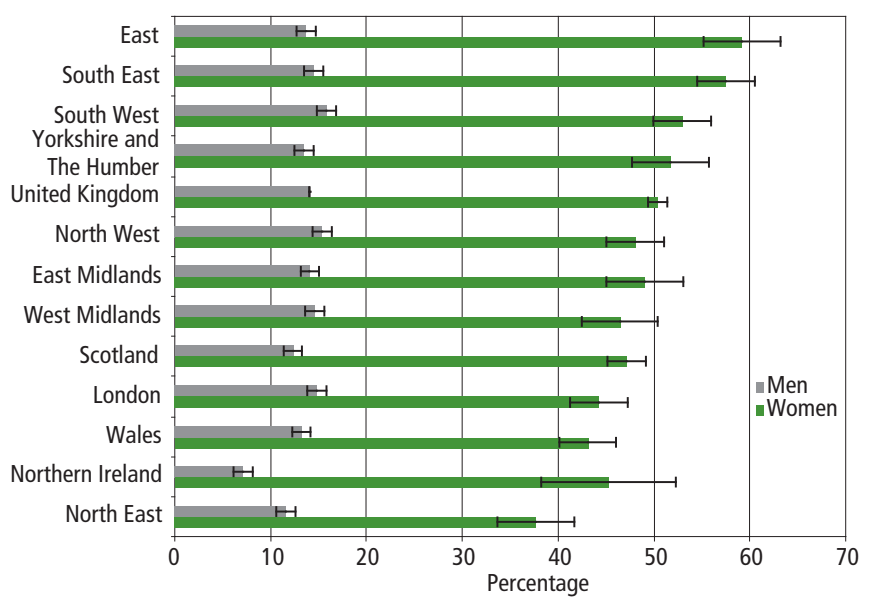

Note: The lines at the end of each bar indicate the range of possible values (95 per cent confidence interval).

1 Self-employed in main job.

Source : Annual Population Survey, Office for National Statistics self-employed women work full-time, the highest percentage of any region.

Although the number of women who are self-employed has increased over the past eight years, a considerable amount of the increase is due to part-time self-employment. This is particularly true in some regions. In the North West the increase between 2000 and 2008 in the number of women who were part-time self-employed was almost four times the increase in those who worked full-time. In the East and South East, increases in those working part-time were more than double the increases in the number of women who were fulltime self-employed. In Wales there was an increase of 43 per cent compared with around 2 per cent for those working fulltime.

\section{Hours worked}

Overall in the UK, women who were full-time self-employed worked on average in excess of 44 hours per week, 4 hours longer each week than full-time female employees. However in Yorkshire and The Humber the average was nearly 6.5 hours more.

The average number of hours worked by women who were part-time self-employed represents two to three days each week. In the East of England, self-employed women working part-time typically worked 14.6 hours per week during the period July 2007 to June 2008, fewer hours than their equivalents in other regions. Women working part-time in the North East worked the longest each week, on average 18.2 hours - the only region where part-time self-employed women worked longer hours than their male counterparts.

However, there are substantial numbers of women who work relatively few hours, as can be seen from Figure 2.9. 


\section{Figure 2.9 Usual hours worked by part-time self-employed' women, July 2007 to June 2008}

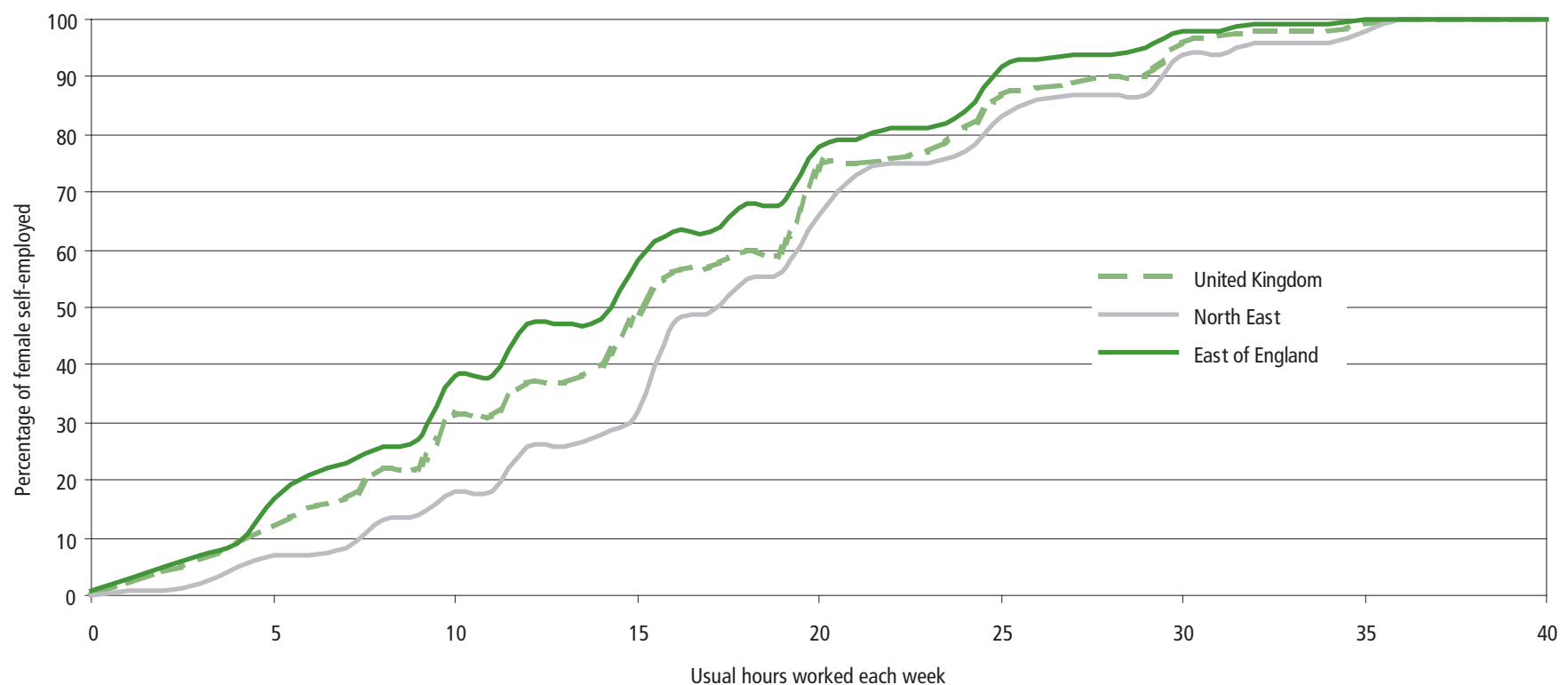

1 Self-employed in main job only.

Source: Annual Population Survey, Office for National Statistics

Approximately one-fifth of part-time self-employed women in the East worked six hours or less each week (left most line on the chart), whereas in the North East (right/lower line on chart) only 7 per cent of self-employed women worked the equivalent of one short day.

As can be seen from the chart there are small proportions of self-employed females in each region who work in excess of 35 hours per week, even though they consider themselves to be part-time.

\section{Sub-regional picture}

Patterns of employment and self-employment vary considerably throughout the UK for both men and women, and variations within regions are often more pronounced than those between regions. However analysis for sub-regions can be limited and, even where estimates are possible, these are less reliable than at regional level and therefore comparisons should be made with care.

The differences in employment and self-employment can be attributed to many factors such as the industrial structure of the area, availability of skills and markets for the products, as well as personal working preferences. Different geographic features can also influence the type of employment. High employment or self-employment in agriculture would obviously be associated with rural rather than urban areas for example. The ease of access to work and whether business can be conducted over the internet has an increasing impact.

Map 2.10 shows women who are self-employed as a proportion of the female population aged 16 or above. In order to improve reliability of estimates some adjacent counties or unitary authorities have been combined ${ }^{5}$. Many areas with higher rates of self-employment match quite closely rural areas such as the western parts of Scotland, central Wales and the South West, as well as bands across North Yorkshire/Cumbria and central England. Sub-regional analysis of Northern Ireland is not possible. A map showing urban/rural patterns for England and Wales can be found on page 111 of the Understanding patterns of deprivation article in this publication. Similar details of rural areas for Scotland can be found at: www.scotland.gov.uk/Publications/ 2004/06/19498/38787

Highest rates of female self-employment of approximately 9 per cent were found in the relatively rural unitary authorities of Powys and Leicestershire, Leicester and Rutland. These contrasted with the urban unitary authorities of Halton (near Liverpool), Blaenau Gwent and Merthyr Tydfil in Wales where rates were about 1 per cent in the July 2007 to June 2008 period. While many urban areas have relatively low selfemployment rates, a few places such as Inner London, Bristol and Brighton and Hove show a different pattern with rates of between 6 and 7 per cent, which is around the national average for full-time self-employed. Brighton and Hove's higher than average female self-employment rate is partly due to a high concentration of creative industries, not found in many other predominantly urban areas.

The North West region illustrates the situation with relatively high rates of women being self-employed in Cumbria ( 6 per cent), but as you move further south towards the region's

5 See Notes and definitions section at the end of this article for details of which areas have been combined. 
Map 2.10 Proportion of women who are self-employed' by local authority², July 2007 to June 2008

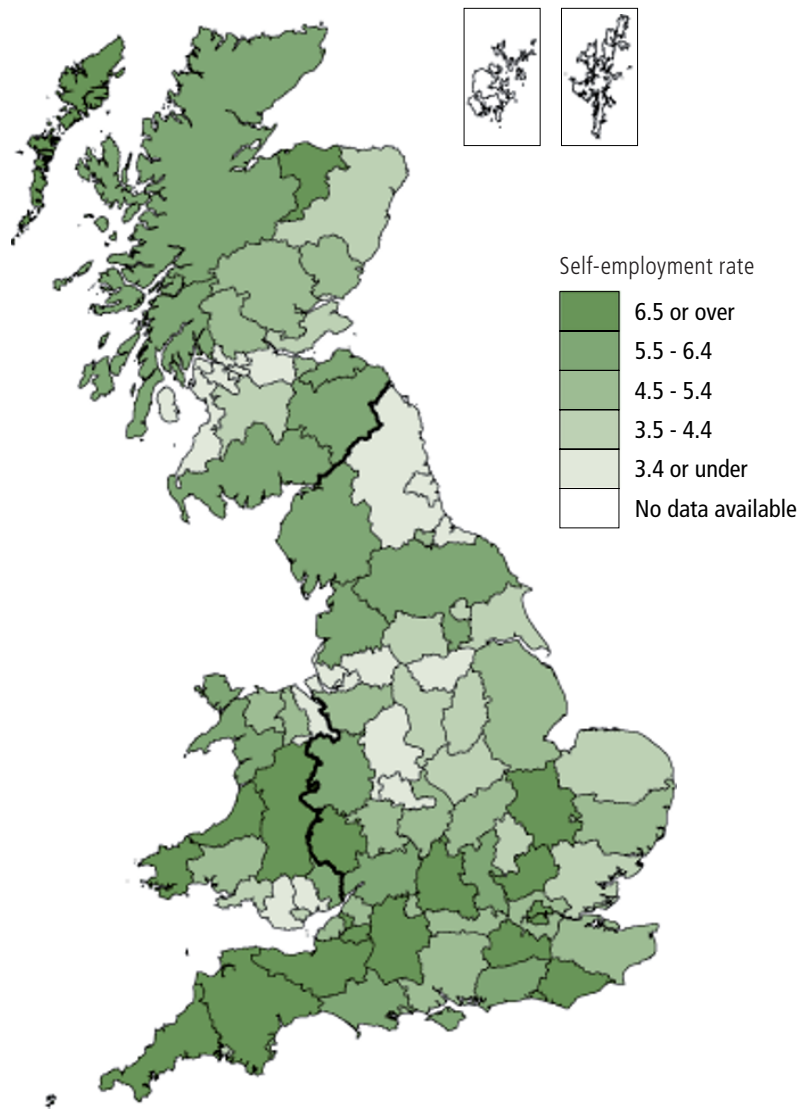

1 Both main and second job self-employed as a percentage of women $16+$ in each area.

2 Some local authorities have been combined, please see Notes and definitions section for details. There are no data for Orkney or Shetland Islands.

Source: Annual Population Survey, Office for National Statistics

industrial heartland this rate falls to 4 per cent in Lancashire and 2 per cent in Merseyside.

\section{Why people become self-employed}

Different factors influence why men and women become selfemployed or own businesses and there are different patterns of female self-employment/business ownership across the country.

The most popular reason given in the Labour Force Survey for becoming self-employed in April to June 2007 was the desire to 'become independent or for a change'. Other key factors given by many were 'because of the nature of the occupation' or 'wanted to make more money'. Despite general similarities between the reasons given by men or women for becoming self-employed there were some significant differences. The most notable difference was that women were nearly five times more likely to mention family reasons for becoming selfemployed than men. A fifth of females chose to work as selfemployed to help combine 'family commitments/wanted to work at home' and employment in a flexible manner.

Conversely, men were almost twice as likely to say that one of the reasons they became self-employed was to 'make more money' than were women.
Table 2.11 Reasons for becoming self-employed', Great Britain, April to June 2007

\begin{tabular}{lrrrr} 
& Women & Men & $\begin{array}{r}\text { Pll } \\
\text { people }\end{array}$ \\
\cline { 2 - 2 } $\begin{array}{l}\text { To be independent / for a } \\
\text { change }\end{array}$ & 26 & 34 & 32 \\
Nature of occupation & 26 & 23 & 24 \\
Family commitments / wanted & 20 & 4 & 8 \\
to work at home & & & \\
Other & 13 & 12 & 12 \\
Opportunity arose - capital, & 10 & 10 & 10 \\
space, equipment available & 9 & 15 & 14 \\
Wanted more money & 9 & 10 & 9 \\
Saw the demand / market & 7 & 8 & 7 \\
For better conditions of work & 6 & 5 & 5 \\
Joined the family business & 4 & 9 & 7 \\
Made redundant & 1 & 2 & 2 \\
No local jobs available & 4 & 5 & 5 \\
No reason given & & & & \\
\hline
\end{tabular}

1 Self-employed in either main job only.

Source: Labour Force Survey 


\section{Figure 2.12 Women who said they became self-employed' for 'family' reasons, April to June 2008}

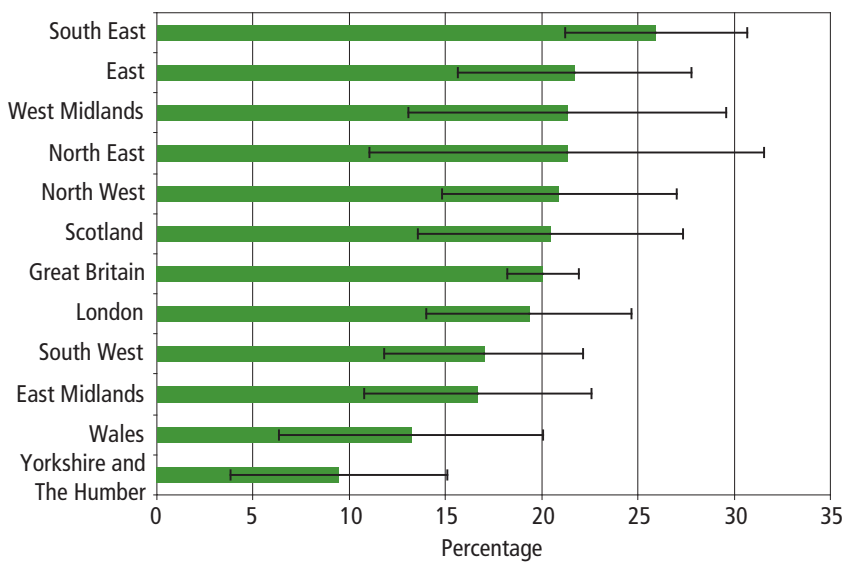

Note: The lines at the end of each bar indicate the range of possible values (95 per cent confidence interval).

1 Self-employed in main job only.

\section{Source: Labour Force Survey, Office for National Statistics}

The most common reasons quoted by people who are selfemployed are similar in each region and country of Great Britain, although the order varies.

However in Yorkshire and The Humber, although independence or wanting a change was still the most popular single reason given by 30 per cent of self-employed females - the second most common reason for becoming self-employed was 'to achieve better working conditions'. This was quoted by 27 per cent of women. Another exception was that in the North West and Yorkshire and The Humber redundancy was the fourth most common reason with more than 12 per cent of women mentioning this factor in the latter region in early 2007. This was despite similar redundancy rates in each region of less than 1 per cent. It should be noted that redundancies have increased markedly since 2007.

The South East had the highest proportion, over a quarter, of self-employed females saying that they chose to work in this way because of family commitments or they wanted to work at home (Figure 2.12). In Yorkshire and The Humber less than 10 per cent and in Wales around 14 per cent of women claimed to be self-employed to allow for family commitments. This illustrates one of the key features of female selfemployment, that rather than working for themselves for particularly entrepreneurial reasons women work for themselves because it is easier to organise their working life around their other responsibilities. This desire to fit work around the rest of their lives is further demonstrated by the greater number of self-employed women who work part-time.

\section{Why do self-employed females work part-time?}

The LFS asks those working part-time why they don't want to work full-time. The main reasons given by self-employed women are that they want to spend more time with their family or that they have domestic commitments (Figure 2.13). In just 2 per cent of cases, a lack of available childcare facilities was mentioned as a reason for not wanting a full-time job.

In the East of England almost 40 per cent of self-employed women working part-time did so in order to spend more time with their families. This was an important reason for at least a quarter of self-employed women in each region. Family and domestic commitments were primary reason for around a quarter of women in Northern Ireland working part-time; this was also the region where women felt least financial necessity to work full-time.

\section{The nature of female self-employment Occupations}

Self-employed women tend to undertake different types of occupations to their male counterparts. The building trades are a notable example, a large proportion of self-employed men work in construction and building related occupations; five of the top ten occupational classes for men are construction related, amounting to about 550,000 jobs in 2008 . This equates to almost a fifth of self-employed males in the UK.

For self-employed women there is less occupational clustering and a total absence of building trades in the most popular occupations. The most popular occupations for men and women in the UK are shown in Table 2.14.

Although the most prevalent occupations nationally feature in the top ten occupations of self-employed women in each region, there are other specific occupations which are important for the local economy. For example, in the West Midlands there appears to be a higher proportion than other regions of women who are self-employed working as accounts clerks and bookkeepers, amounting to around 5 per cent of the self-employed women in the region. Also, in London almost 12 per cent of the self-employed women $(20,000$ individuals) are engaged in the creative sector as producers, actors, writer and designers etc. Creative industries are also well represented by women in the North West, the South East and Yorkshire and The Humber as authors and in the South West as artists. Farmers and farm workers account for over 5 per cent of self-employed women in Wales.

Overall, childminding and related occupations are the most common type of self-employment for women, accounting for around 5 to 7 per cent of the total in most regions. However, in Northern Ireland this group of occupations accounts for about twice this proportion. While childminding may not be considered particularly entrepreneurial, the availability of good, accessible childcare can be a major factor in allowing others to engage in entrepreneurial activity. In England there are registered childcare places for about half of the under five population. The North West and South West have the highest number of places relative to under fives with 57 and 56 per cent respectively, whereas provision is lowest in London, the South East and Yorkshire and The Humber, catering for 41, 45 and 45 per cent respectively of the target population. 


\section{Figure 2.13 Reasons for self-employed ${ }^{1}$ women not wanting full-time job}

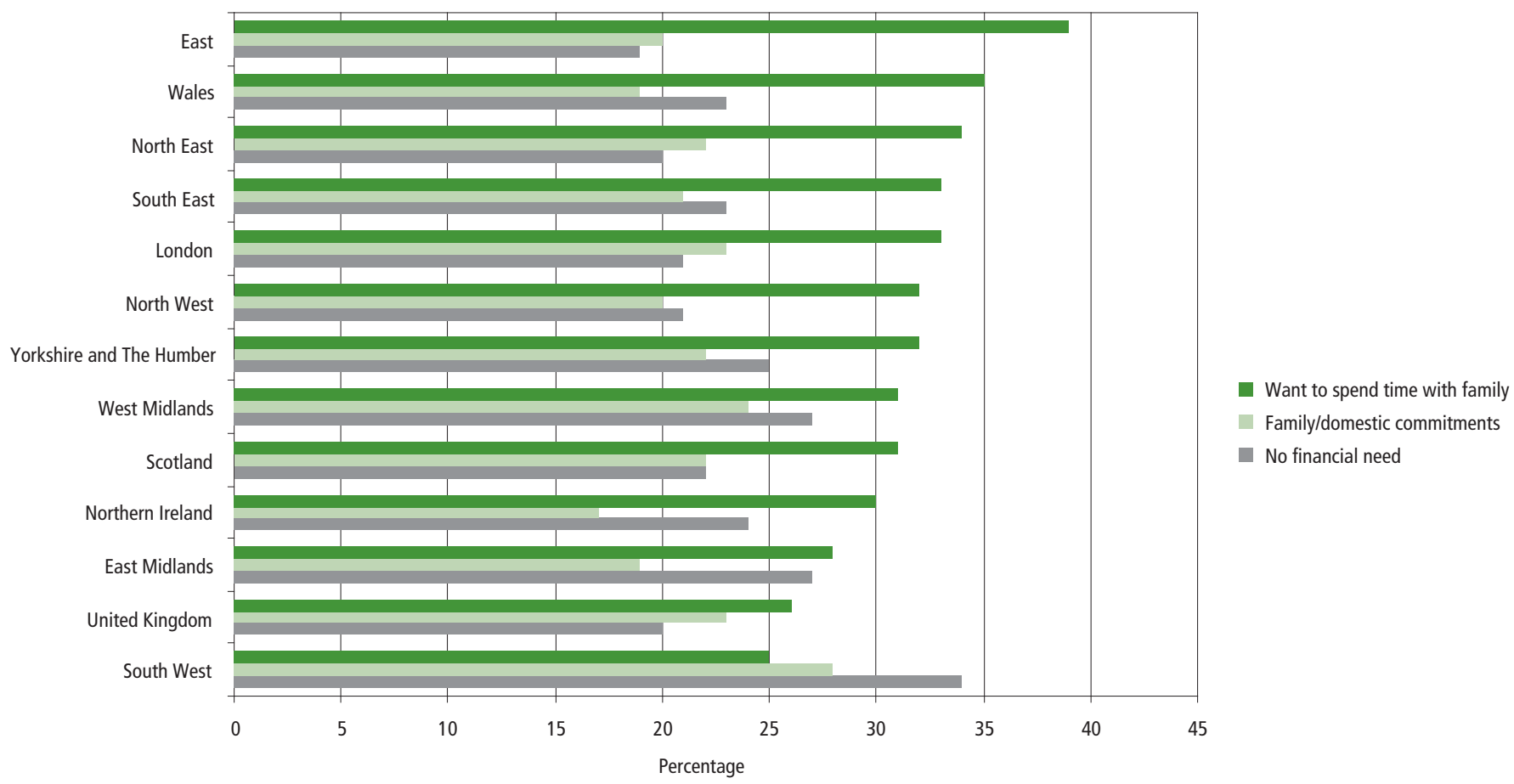

Note: Based on data from four quarters of LFS October to December 2006 and 2007 and April to June 2007 and 2008.

1 Self-employed in main job only.

Source: Labour Force Survey, Office for National Statistics

Table 2.14 Most prevalent occupations of the self-employed in the UK, July 2007 to June 2008

\begin{tabular}{|c|c|c|c|c|}
\hline & Men & Thousands & Women & Thousands \\
\hline 1 & Construction trades n.e.c. (5319) & $178(6 \%)$ & $\begin{array}{l}\text { Childminders and related occupations } \\
(6122)\end{array}$ & $80(7 \%)$ \\
\hline 2 & Taxi cab drivers and chauffeurs (8214) & $153(5 \%)$ & Teaching professionals n.e.c. (2319) ${ }^{3}$ & $55(5 \%)$ \\
\hline 3 & Carpenters and joiners (5315) & $140(5 \%)$ & Cleaners, domestics (9233) & $52(4 \%)$ \\
\hline 4 & Painters and decorators (5323) & $90(3 \%)$ & $\begin{array}{l}\text { Shopkeepers, wholesale \& retail dealers } \\
(1234)\end{array}$ & $50(4 \%)$ \\
\hline 6 & Farmers (5111) & $81(3 \%)$ & $\begin{array}{l}\text { Accounts, wages clerks \& bookkeepers } \\
(4122)\end{array}$ & $40(3 \%)$ \\
\hline 7 & $\begin{array}{l}\text { Shopkeepers, wholesale \& retail dealers } \\
(1234)\end{array}$ & $76(2 \%)$ & Therapists n.e.c. $(3229)^{4}$ & $36(4 \%)$ \\
\hline 8 & Gardeners and grounds(wo)men (5113) & $74(2 \%)$ & $\begin{array}{l}\text { Beauticians and related occupations } \\
(6222)\end{array}$ & $30(2 \%)$ \\
\hline 10 & Managers in construction (1122) & $60(2 \%)$ & Medical practitioners (2211) & $23(2 \%)$ \\
\hline 11 & Retail and wholesale managers (1163) & $56(2 \%)$ & Hotel and accommodation (1221) & $20(2 \%)$ \\
\hline 12 & Bricklayers, masons (5312) & $47(2 \%)$ & $\begin{array}{l}\text { Managers and proprietors in other } \\
\text { services (1239) }\end{array}$ & $20(2 \%)$ \\
\hline 13 & $\begin{array}{l}\text { Labourers, building \& woodworking } \\
\text { trades }(9121)\end{array}$ & $47(2 \%)$ & Authors, writers (3412) & $20(2 \%)$ \\
\hline & Total self-employed men & 2,987 & Total self-employed women & 1,220 \\
\hline
\end{tabular}

1 Four digit codes from Standard Occupational Classification 2000 (SOC 2000) are included in brackets after description. n.e.c. means not elsewhere classified.

2 This code includes: Builder (building and contracting), Builder and decorator, Building contractor, General builder, Steel fixer, Steeplejack.

3 This code includes: Examiner (examination board), Nursery manager (day nursery), Owner (children's nursery), Principal (dancing school/evening institute), Private tutor, Teacher of English as a foreign language, TEFL.

4 This code includes: Acupuncturist, Dietician, Masseur, Orthoptist, Osteopath, Psychotherapist. 
Cost of childcare is also an issue ranging from $\mathrm{f115}$ per week in the West Midlands to $f 196$ in Inner London ${ }^{6}$.

Figure 2.15 shows regional differences in the proportion of self-employed women by broad occupational group.

The proportion of self-employed females who are managers or senior officials ranges from around 14 per cent in London to roughly double that proportion in Northern Ireland. This group includes chief executives, directors and bank managers. As mentioned earlier, there are some differences in the composition of the self-employed group compared with the business owners group, and that business owners tend to be in more senior occupations than the self-employed.

The associate professional and technical group covers such diverse occupations as nurses and sports professionals, together with a range of creative people such as artists, journalists and web designers. Over a third of self-employed women in London fall into this category. Associate professionals account for a fifth or more of self-employed women in each region of the Greater South East (London, the East and South East) and the West Midlands.

Regional disparity in professional occupations such as doctors, teachers or lawyers is less marked with between 8 and 15 per cent of self-employed females in each region belonging to this group. In the South East 15 per cent of self-employed women work in personal services, this rises to 27 per cent in Northern Ireland. These occupations can be as diverse as a croupier, or dental nurse to an air hostess. Skilled trades such as a farmer, chef or electrician, account for only a small proportion, four to eight per cent, of women who are self-employed.

Administrative and secretarial work includes bank and filing clerks as well as telephone interviewers and around a tenth of self-employed women fall into this group in the South East and West Midlands. However, in the North East this group accounts for only three per cent.

Occupation groups 7, 8 and 9 account for small proportions of self-employed women in each region. Group 7 relates to sales people which can range from cashiers in shops and restaurants to those who are more creative such as window dressers. Process plant and machine operatives account for a very small proportion of self-employed women, with Northern Ireland having the highest proportion at 5 per cent. Elementary occupations include people working as labourers, couriers and cleaners.

\section{Industry}

In line with different occupations undertaken by the selfemployed, the industries in which women work, are very different from the most prevalent industries for men. Selfemployed men are dominant in construction and building related enterprises, whereas women work in a greater variety

6 According to the Childcare Cost Survey, 2009 conducted by the Daycare Trust. Figures quoted are average childminding charges for an under 2 year old, nursery charges are approximately $\$ 25-£ 30$ higher per week. of industries with higher concentrations in retail trade, social work and service industries. Examples of the most prevalent industries for women and men throughout the UK are shown in Table 2.16. This level of industrial breakdown is not possible for individual regions due to the small numbers involved in some categories.

Figure 2.17 illustrates the proportions of self-employed women in the various industry groups. Other service industries accounted for between 18 per cent in Northern Ireland and 30 per cent in London of self-employed women. Self-employed women were also well-represented in the public sector, which includes those engaged in education and health as well as defence and administration At least a fifth of all self-employed women in each region were engaged in the public sector, with the lowest proportions in the East and West Midlands, rising to around one-third in the North East.

Banking, finance and insurance is another sector accounting for a large proportion of self-employed women - 15 to 25 per cent in each region. The highest proportions were found in London and the South East.

Small proportions of women work in the remaining industry groups, although in Wales nearly 8 per cent work in agriculture, forestry and fishing and a similar percentage work in manufacturing in the East Midlands. In many regions about a fifth of self-employed women work in the distribution, hotels and restaurants sector but in London this was less than 10 per cent, increasing to about 25 per cent in Wales.

Many regions show a similar pattern in the proportions of selfemployed women and men working in various industries. Charts showing the proportions self-employed women and men in each industry group for each region are available on the website: www.statistics.gov.uk/regionaltrends.

\section{Homeworking}

Survey data on homeworking practices reveal some significant differences between the working habits of self-employed men and women.

Figure 2.18 shows that in each region self-employed women are significantly more likely to work at home than their male counterparts. On average about 30 per cent of self-employed women and 8 per cent of men work at home, the difference is slightly less marked in London where around 11 per cent of men work at home compared with 29 per cent of women. A major part of this difference can no doubt be attributed to variations in occupational structures (for example it makes little sense for those in building related occupations to work at home). However, even in industries and occupation in which both women and men work, there is a greater likelihood that women will work at home than there is for men. For example, approximately 18 per cent of self-employed female shopkeepers work from home, which is double the proportion for males. Even for medical practitioners the proportion working from home is slightly higher for women than men. 
Figure 2.15 Proportions of self-employed ${ }^{1}$ women by occupational group, July 2007 to June 2008
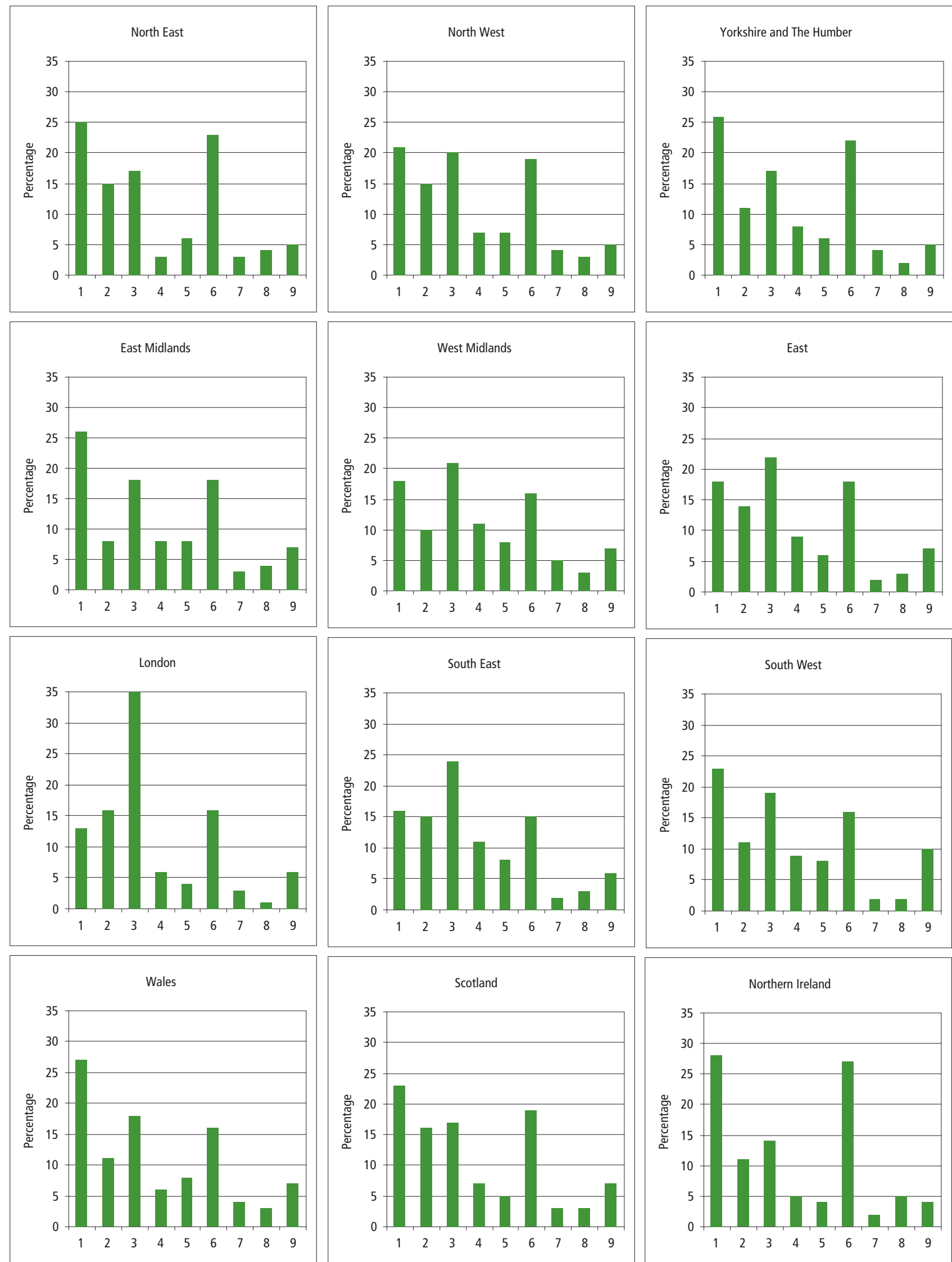

Key to occupation groups

1 Managers and senior officials

2 Professional occupations

6 Personal service occupations

3 Associate professional and technical

4 Administrative and secretarial

7 Sales and customer service occupations

5 Skilled trades occupations

8 Process plant and machine operatives

9 Elementary occupations

1 Self employed in main job only

Source: Annual Population Survey, Office for National Statistics 
Table 2.16 Most prevalent industries of the self-employed in the UK, July 2007 to June 2008

\begin{tabular}{|c|c|c|c|}
\hline Men & Thousands (\%) & Women & Thousands (\%) \\
\hline $\begin{array}{l}\text { Building, demolishing \& earth moving } \\
(45.11-45.50)^{1}\end{array}$ & $872(29 \%)$ & Retail trade (52.11-52.63) & $118(10 \%)$ \\
\hline Retail trade (52.11-52.63) & $162(5 \%)$ & $\begin{array}{l}\text { Social work without accommodation } \\
\text { (85.32) }\end{array}$ & $99(8 \%)$ \\
\hline Taxi (60.22) & $153(5 \%)$ & $\begin{array}{l}\text { Hairdressing, other beauty treatment } \\
(93.02)\end{array}$ & $83(7 \%)$ \\
\hline $\begin{array}{l}\text { Architect, engineering etc consultancy } \\
(74.20)\end{array}$ & $86(3 \%)$ & $\begin{array}{l}\text { Private households with employed persons } \\
\text { (95) }\end{array}$ & $51(4 \%)$ \\
\hline $\begin{array}{l}\text { Accounting, auditing, tax consultancy } \\
\text { (74.12) }\end{array}$ & $76(3 \%)$ & Artistic, literary, creation etc. (92.31) & $50(4 \%)$ \\
\hline Artistic, literary, creation etc. (92.31) & $69(2 \%)$ & $\begin{array}{l}\text { Accounting, auditing, tax consultancy } \\
\text { (74.12) }\end{array}$ & $41(3 \%)$ \\
\hline Computer software consultancy $(72.20)$ & $62(2 \%)$ & Other human health activities (85.14) & $40(3 \%)$ \\
\hline Motor vehicle repair (50.20) & $60(2 \%)$ & Medical practice activities (85.12) & $30(2 \%)$ \\
\hline Wholesale (51.21-51.70) & $52(2 \%)$ & Adult other education (80.42) & $29(2 \%)$ \\
\hline Farming: cattle dairy (1.21) & $51(2 \%)$ & Industrial cleaning (74.70) & $24(2 \%)$ \\
\hline Total self-employed Men & 2,987 & Total self-employed Women & 1,220 \\
\hline
\end{tabular}

1 Industrial codes (in brackets) relate to Standard Industrial Classification 2003.

Source: Annual Population Survey, July 2007 to June 2008, Office for National Statistics

Nationally about 30 per cent of self-employed women work at home. In Northern Ireland, the East and South East the proportion is above average at around a third of women working at home. This compares with the North West which has the lowest proportion about 20 per cent. However, if one includes being based in the grounds of your home, Wales has the second highest proportion of those regularly working at or close to home after Northern Ireland - more than two-fifths of self-employed women in each of the areas. Figure 2.19 shows location of where self-employed women work as a proportion of self-employed women in each region.

The type of industry mix in each region and the occupations of the self-employed women will influence whether working from home is an option. Personal preference will also play a major part in the decision about whether or not to work at home. National details of where key self-employed occupations work is given in Table 26 of the report 'Female owned businesses in the South East'.?

\section{Size of business}

The size of business that the self-employed own can be used as an indicator of the quality of jobs available; formal selfemployment is more likely to employ staff than informal and transitory self-employment. Nationally, 82 per cent of selfemployed women work alone or with a partner, about 5 percentage points higher than for self-employed men. Figure 2.20 shows the highest proportions of self-employed women working alone are in London with 87 per cent, the East of England and the South East, and the lowest are in Northern Ireland and the North East where just 70 per cent work on their

7 Females in businesses in the South East: www.see-in.co.uk/downloads/ ONS\%20Documents/FIB\%20final\%20July08.pdf own. Interestingly the highest rates of female self-employment correspond with regions where self-employed females are most likely to work on their own.

\section{Income from self-employment}

There are substantial disparities between regions in the income of self-employed women, see Figure 2.21. Whereas 60 per cent of self-employed women in the North East had incomes of $\mathbf{f 1 0 , 0 0 0}$ or less in 2006/07, a little under half those in London, the South East and East of England earned this amount. Similarly, the proportion of self-employed women who earned less than $f 5,035$ in the North East was 4 percentage points higher than the proportion across the UK as a whole (11 per cent and 7 per cent respectively).

\section{Measuring business ownership}

So far this article has concentrated on the most easily analysed sub-set of business owners, the self-employed. However it is important to remember that a further group of business owners exist, these are the employee owners of incorporated businesses (employee business owners). Analysis of this group reveals a more accurate picture of differences in business ownership of women between regions and between men and women within regions.

Estimates of employee business owners are only available from the LFS in the April-June quarter every other year; those respondents who indicate that they are managers of private sector enterprises are asked whether or not they own the business that they work for. Through a combination of the employee estimate of employee business owners, and estimates of the self-employed an estimate of the total number of business owners can be achieved. 
Figure 2.17 Proportion of self-employed ${ }^{1}$ women by industry group, July 2007 to June 2008
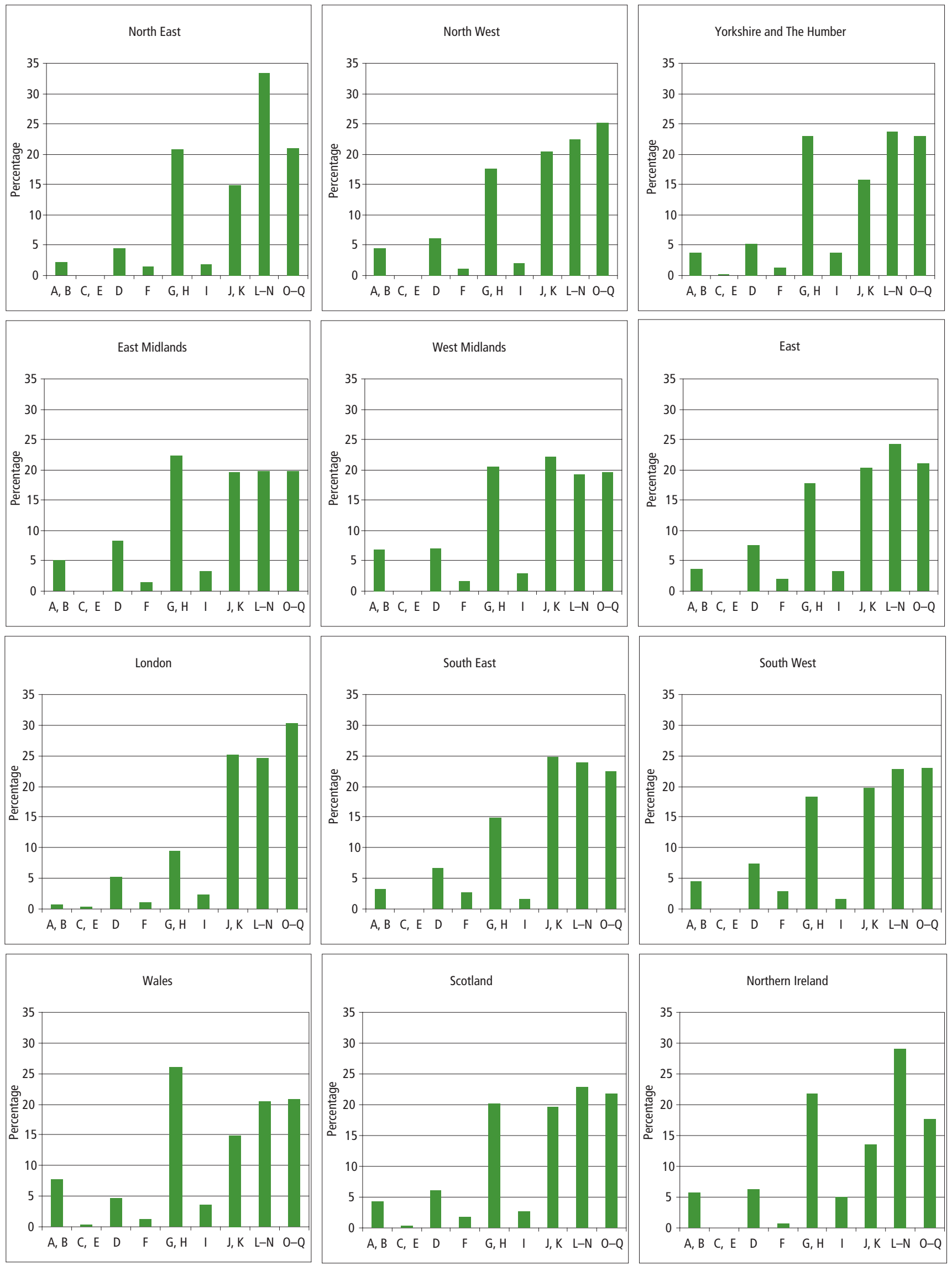

Key to industry groups:
A, B: Agriculture \& fishing
I: Transport \& communication
C, E: Energy \& water
K. Banking finance $\&$ insurance etc
D: Manufacturing
L-N: Public admin education \& health
F: Construction
O-N: Public admin education \& health
G, H: Distribution hotels \& restaurants

1 Self-employed in main job only. 
Figure 2.18 Percentage of self-employed' working mainly in own home

Northern Ireland

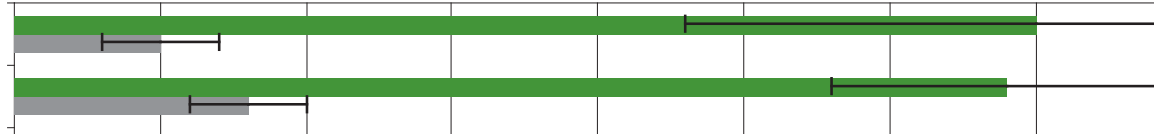

South East

South West

Scotland

United Kingdom

Yorkshire and The Humber

$$
\begin{array}{r}
\text { London } \\
\text { East Midlands } \\
\text { West Midlands } \\
\text { Wales } \\
\text { North East } \\
\text { North West }
\end{array}
$$
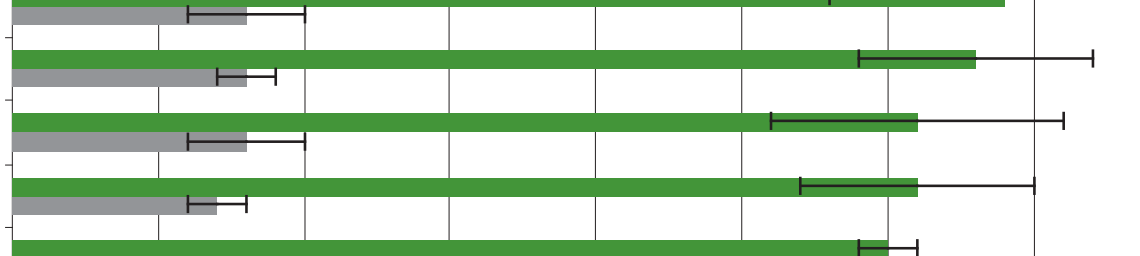

$$
\text { - }
$$

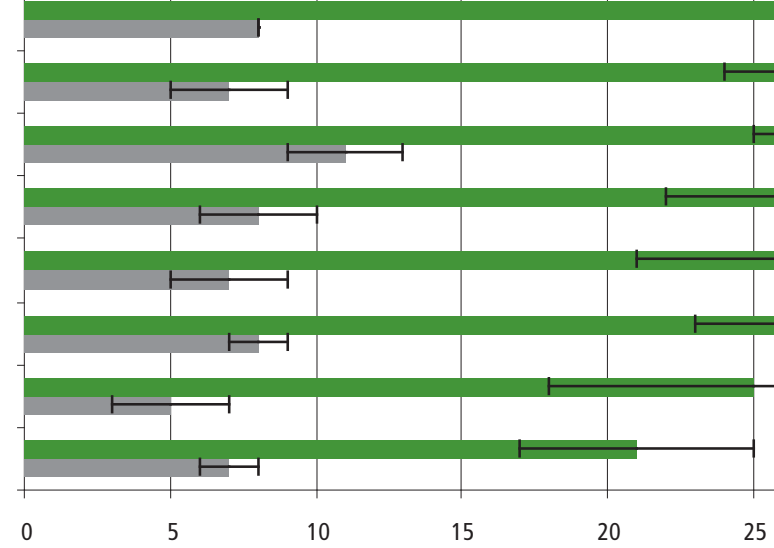

0

20

Percentage of self-employed

Note: The lines at the end of each bar indicate the range of possible values ( 95 per cent confidence interval).

1 Self-employed in main job only.

Source: Annual Population Survey, Office for National Statistics

Figure 2.19 Main place of work for self-employed' women, July 2007 to June 2008

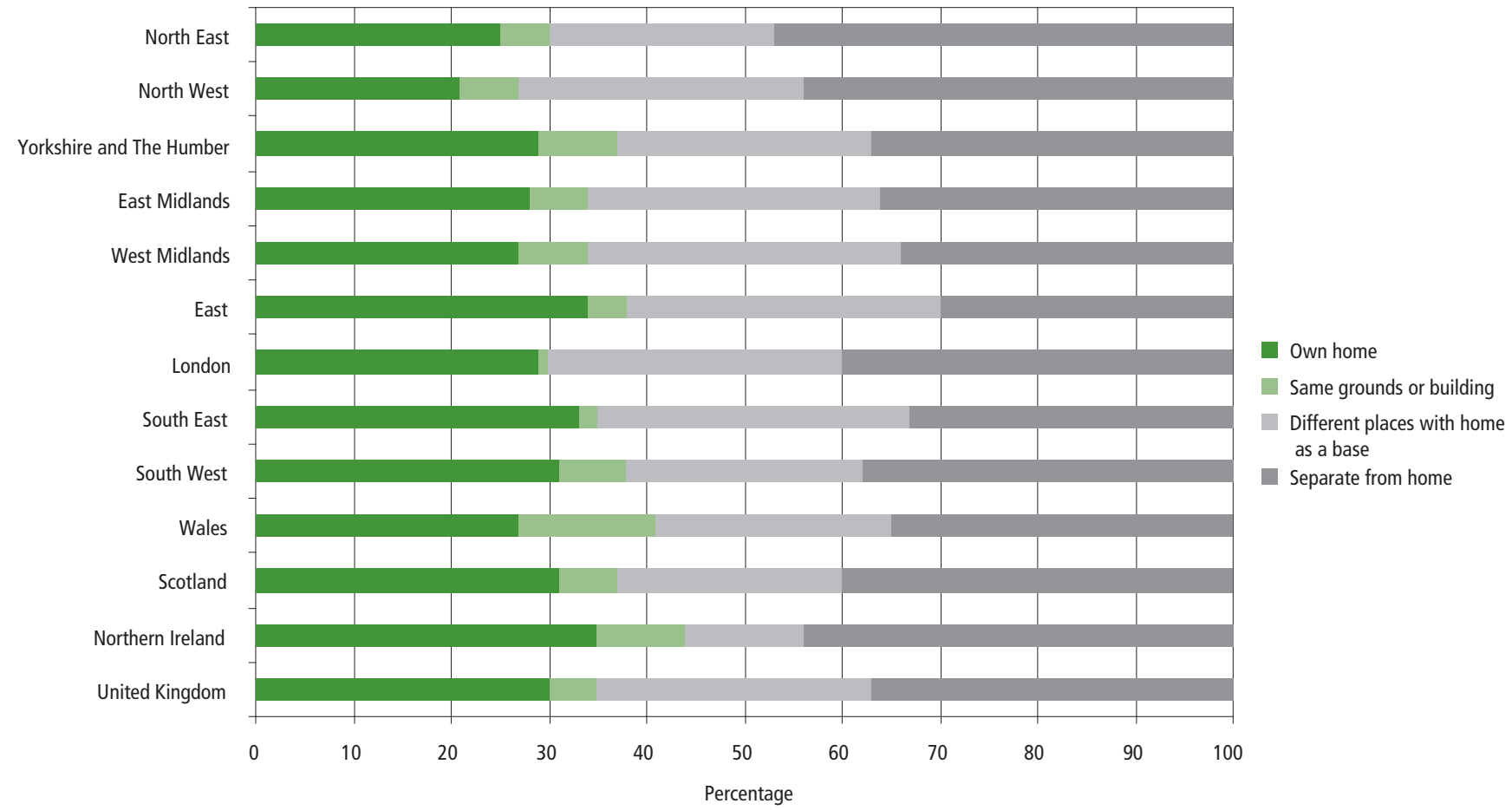

1 Self-employed in main job only.

Source: Annual Population Survey, Office for National Statistics 


\section{Figure 2.20 Percentage of self-employed ${ }^{1}$ women working alone, July 2007 to June 2008}

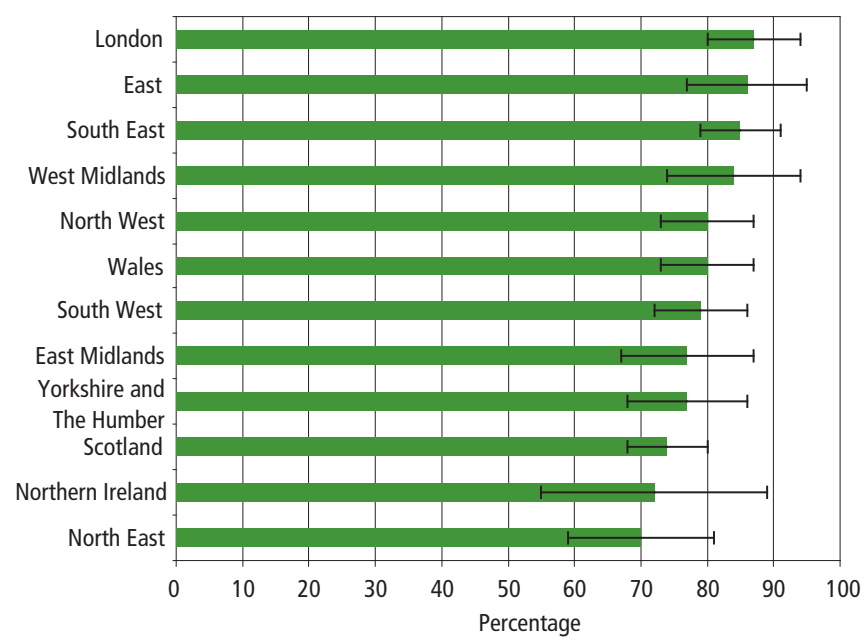

Note: The lines at the end of each bar indicate the range of possible values (95 per cent confidence interval).

1 Self-employed in main-job only.

Source: Annual Population Survey, Office for National Statistics

\section{Two types of business owners}

Self-employed (owner-managers of un-incorporated businesses). This is the most common form of business ownership, the owner of the business and the enterprise constitute one legal entity. The businesses owned by people in this category are often small and employ few staff. The number of self-employed is a regular output from the Labour Force Survey.

\section{Employee owners of incorporated businesses.}

These are workers who hold a job in an incorporated enterprise, in which they: (a) alone, or together with other members of their families or one or a few partners, hold controlling ownership of the enterprise; and (b) have the authority to act on its behalf as regards contracts with other organizations and the hiring and dismissal of persons in 'paid employment' with the same organization, subject only to national legislation regulating such matters and the rules established by the elected or appointed board of the organization. The number of employee owners is available from the Labour Force Survey from one quarter every two years.

Figure 2.21 Self-employed income for women, 2006/07

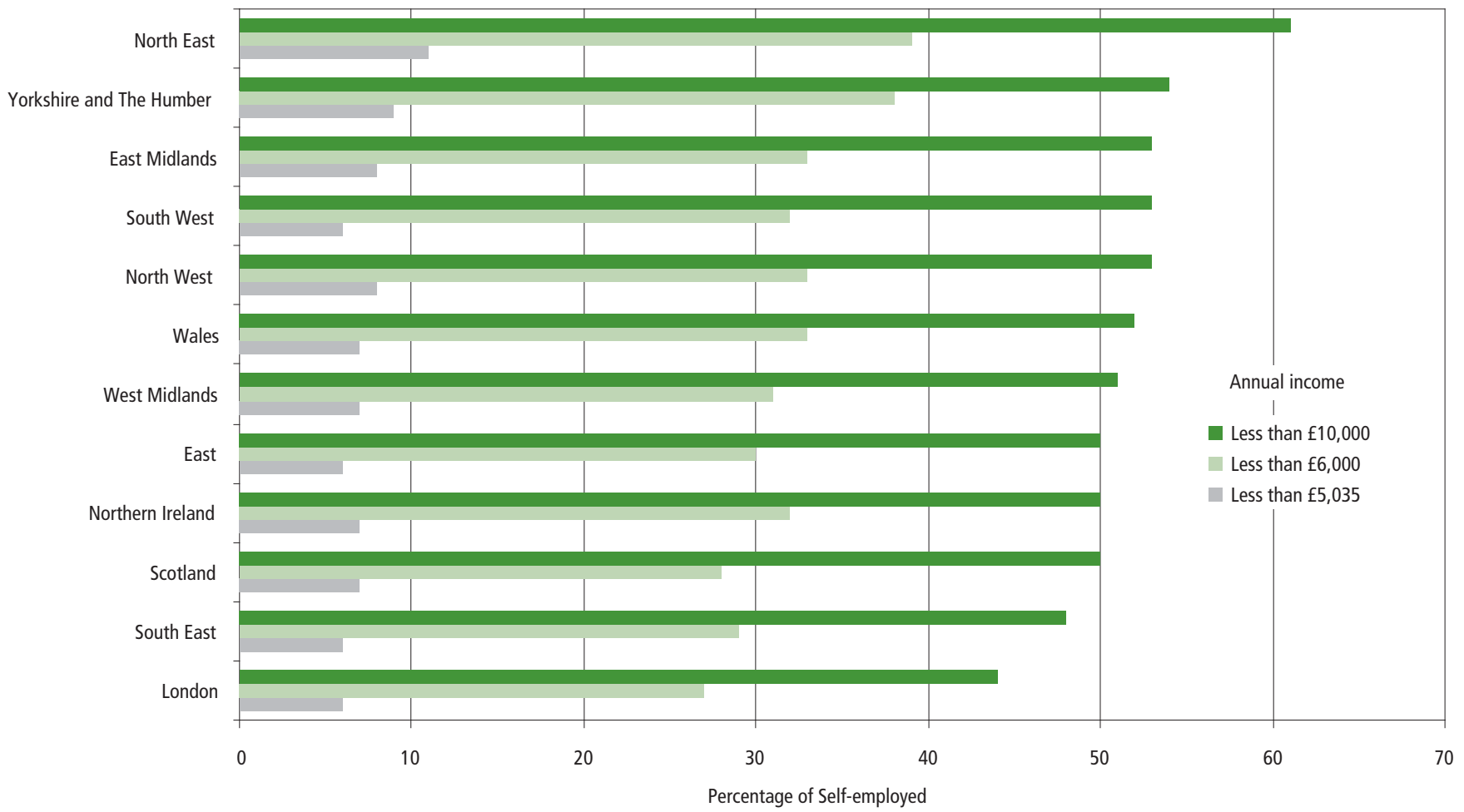

Note: In the tax year 2006/07, f5,035 represented the threshold at which individuals were eligible for paying income tax. 
Figure 2.22 shows the estimated composition of women business owners. The estimates of those self-employed in their first and second job will include some people who are actually employee business owners; however for practical reasons no attempt has been made to re-classify these individuals. The disparities in the proportions of employee business owners in each region are different to the variations in self-employment rates. In particular, in the South East, the East and the South West the total female business ownership rate is about one percentage point higher than the self-employment rate. There is less impact in the North West, Yorkshire and The Humber and Northern Ireland where the addition of 'business owners' to the self-employed leads to an increase of less than 0.3 percentage points in each area.

Whereas nationally nearly 29 per cent of the self-employed are women, just 22 per cent of employee business owners are women. Although the difference between the overall estimate of business owners and the estimate of the self-employed is greatest in the South East, the addition of employee business owners actually increases the disparity between the business ownership rates for men and women in the region (see Table 2.23). For details of the confidence intervals relating to selfemployment data please see Table 2.26 in the Notes on sources section.

Indeed, only in one region, the North East, does the addition of employee owners of incorporated enterprises close the gap between the proportion of male and female business owners. The greatest disparity between male and female employee business owners and self-employees is in London, where
Table 2.23 Summary of female business activity, April to June 2008

\begin{tabular}{lcrr} 
& $\begin{array}{r}\text { Percentage of } \\
\text { self-employed } \\
\text { who are women }\end{array}$ & $\begin{array}{r}\text { Percentage of } \\
\text { employee owners } \\
\text { who are women }\end{array}$ & $\begin{array}{r}\text { Percentage of all } \\
\text { business owners } \\
\text { in region who } \\
\text { are women }\end{array}$ \\
\hline North East & 29 & 33 & 30 \\
North West & 26 & 16 & 25 \\
Yorkshire and & 28 & 22 & 27 \\
The Humber & 28 & 24 & 27 \\
East Midlands & 27 & 19 & 25 \\
West Midlands & 29 & 28 & 29 \\
East & 28 & 14 & 26 \\
London & 32 & 25 & 31 \\
South East & 32 & 23 & 31 \\
South West & 26 & 19 & 25 \\
Wales & 31 & 29 & 31 \\
Scotland & 21 & 20 & 21 \\
Northern Ireland & 29 & 22 & 28 \\
United Kingdom & & & \\
\hline
\end{tabular}

Source: Labour Force Survey, Office for National Statistics

females account for 28 per cent of the self-employed, but just 14 per cent of employee business owners.

Table 2.24, derived from LFS data for April to June 2008, shows rates which could be utilised to give estimates of business ownership in the intervening period prior to new estimates from the LFS being released in Spring 2010.

\section{Figure 2.22 Business ownership rates for women, April to June 2008}

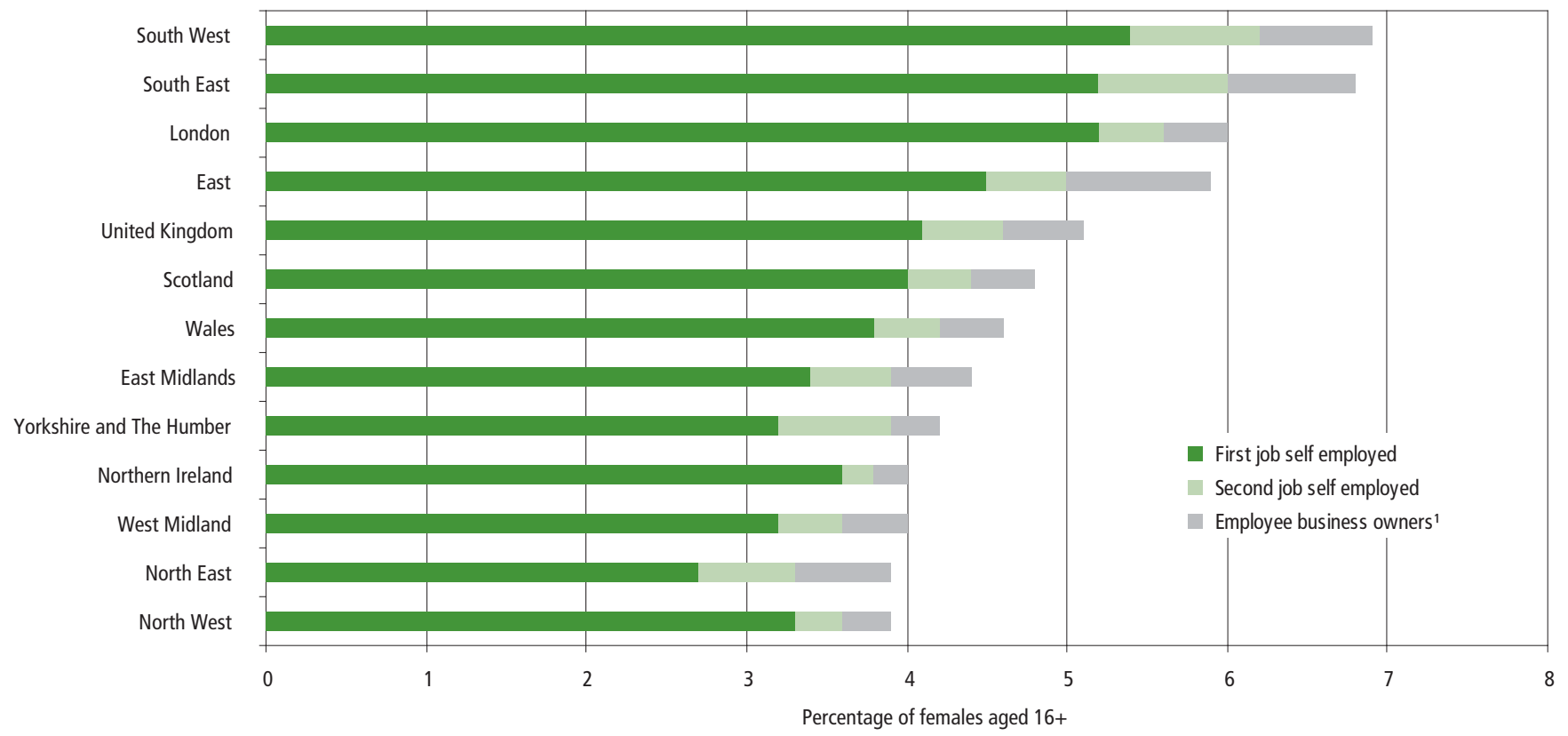

1 The estimate of employee business owners is an underestimate; a proportion of those who self-classify themselves as self-employed are technically employee business owners. 
Table 2.24 Differences between selfemployed and business owners, April to June 2008

\begin{tabular}{lrr} 
& \multicolumn{2}{c}{$\begin{array}{c}\text { Percentage increase between } \\
\text { self-employed and business }\end{array}$} \\
\cline { 2 - 3 } North East & Women & Men \\
\cline { 2 - 3 } North West & 19 & 16 \\
Yorkshire and The Humber & 8 & 14 \\
East Midlands & 7 & 10 \\
West Midland & 13 & 16 \\
East & 12 & 19 \\
London & 17 & 18 \\
South East & 7 & 16 \\
South West & 13 & 20 \\
Wales & 11 & 17 \\
Scotland & 10 & 15 \\
Northern Ireland & 10 & 11 \\
United Kingdom & 7 & 7 \\
\hline
\end{tabular}

Source: Labour Force Survey, Office for National Statistics

Unfortunately the LFS cannot provide robust analysis of all the characteristics of female employee business owners by region?, due to relative rarity of people in this category. In the South East, the region with the most female employee business owners, there are around 30,000; in many other regions they number substantially less than 10,000. An estimate of 10,000 from the LFS is generally regarded as the smallest that can be used with any confidence and obviously estimates of this size cannot be further sub-divided.

Women employee business owners are more similar to male business owners than to self-employed women. About half of self-employed women work full-time, whereas the proportion for women business owners is two-thirds. The industrial composition of women employee business owners is also more similar to that for male business owners than to self-employed women.

\section{Conclusions}

Self-employment constitutes around 90 per cent of business ownership for both men and women and is therefore often used as a proxy. But although this may be a quantitative indicator it gives little guide as to the quality of the business activity. For some analysis this is acceptable, but this measure has limitations, and may indeed be misleading, in terms of entrepreneurial activity or businesses which could grow to create additional jobs.

8 Nationally there are just over 100,000 female employee business owners.
For example, high levels of self-employment need to be interpreted carefully as they may not necessarily be an indicator of a high level of entrepreneurial activity. A substantial proportion of self-employed women are motivated by convenience and working around family commitments and may be working very few hours - as little as an hour per week.

Regions with high levels of female self-employment tend to have a higher proportion of 'family commitment' type of activity, often characterised by part-time working and above average proportions of home working than areas with lower self-employment.

In recent times the level and rate of female self-employment has been growing steadily across the UK. Rates and numbers are highest in the South East, South West and London, and lowest in Northern Ireland and the North East. However, the highest rate for women who are full-time self-employed, which may be more closely related to business ownership, is in London; the South East and South West have comparatively high proportions of part-time working.

While the growth in self-employment amongst women is encouraging, the nature of the increase may be less so. In some locations the growth is mainly as a result of part-time working, possibly working very few hours. The number of self-employed women working full-time has remained relatively stable in recent times.

Encouraging wider business ownership and entrepreneurship amongst women are important policies for many regions and there are numerous initiatives to promote these and to improve understanding of women in the workplace.

Business ownership is measured by the Labour Force Survey, but only on an infrequent basis. Measuring entrepreneurship is even more difficult, not least because the concept is ill-defined. Business ownership is deemed to be an appropriate measure for entrepreneurship, but not all business owners may be engaged in entrepreneurial activity or in expanding their business. Therefore, in order to monitor the effectiveness of initiatives it is advisable to develop a range of proxy measures which will undoubtedly include estimates of self-employment.

For all its limitations, estimation of self-employment is carried out regularly as part of labour market reporting and is therefore easily accessible and relatively up-to-date. Selfemployment is a major component of business ownership and levels are high enough to enable some analysis at regional level. Changes in self-employment are very similar to those in business ownership. Self-employment may also be a stepping stone to businesses which employ others or engage in enterprise activity. 


\section{Notes and definitions}

\section{Entrepreneurship}

Definitions are varied, but it is often considered to be the practice of starting a new business or the re-vitalisation of an existing one usually through innovation. Entrepreneurs have the ability to spot business opportunities and come up with new ideas to deliver desired outcome, they take and manage risks, and to do so with determination and drive.

The two components of the business owners group

The following definitions of self-employment and ownermanagers of incorporated enterprises come from the International Labour Organisation classifications (see www. ilo.org/public/english/bureau/stat/class/icse.htm). As can be seen from the definitions below, different interpretations may be required of ownership or self-employment in various circumstances to obtain a realistic picture of the situation.

Self-employment jobs are those jobs where the remuneration is directly dependent upon the profits (or the potential for profits) derived from the goods and services produced (where own consumption is considered to be part of profits). The incumbents make the operational decisions affecting the enterprise, or delegate such decisions while retaining responsibility for the welfare of the enterprise. (In this context 'enterprise' includes one-person operations.)

Owner managers of incorporated enterprises are workers who hold a job in an incorporated enterprise, in which they: (a) alone, or together with other members of their families or one or a few partners, hold controlling ownership of the enterprise; and (b) have the authority to act on its behalf as regards contracts with other organizations and the hiring and dismissal of persons in 'paid employment' with the same organization, subject only to national legislation regulating such matters and the rules established by the elected or appointed board of the organization. Different users of labour market, economic and social statistics may have different views on whether these workers are best classified as in 'paid employment' or as in 'self-employment' (see self-employment jobs), because these workers receive part of their remuneration in a way similar to person in 'paid employment' while their authority in and responsibility for the enterprise corresponds more to persons in 'selfemployment', and in particular to 'employers'. (Note, for example, that to classify them as 'employees' will be consistent with their classification in the System of National Accounts, while they may be best classified as 'employers' or 'own-account workers' for labour market analysis.) Countries should, therefore, according to the needs of users of their statistics and their data collection possibilities, endeavour to identify this group separately. This will also facilitate international comparisons.
Home-working When people used their own home as the main location from which they pursue their business. As with all LFS questions this is self-assessed.

\section{Standard Industrial Classification 2003 (SIC 2003)}

This is used to classify business establishments and other standard units in the UK by the type of economic activity in which they are engaged. It provides a framework for the collection, tabulation, presentation and analysis of data and its use promotes uniformity. In addition, it can be used for administrative purposes and by non-government bodies as a convenient way of classifying industrial activities into a common structure.

www.statistics.gov.uk/statbase/Product.asp?vlnk=14012

Standard Occupational Classification 2000 (SOC 2000)

This is used to classify the different types of occupations carried out. The two main concepts of the classification are:

- kind of work performed - job

- competent performance of the tasks and duties - skill.

Details may be found at www.statistics.gov.uk/methods_quality/soc/structure.asp

Full structure:

www.statistics.gov.uk/methods_quality/ns_sec/ downloads/SOC2000.doc

Inter-Departmental Business Register (IDBR)

ISBR is a list of UK businesses maintained by the Office for National Statistics (ONS) and combines the former Central Statistical Office (CSO) VAT based business register and the former Employment Department (ED) employment statistics system. It complies with European Union regulation 2186/93 on harmonisation of business registers for statistical purposes. Details may be found at www.statistics.gov.uk/ idbr/idbr.asp

However, the gender of owners (or senior partners) is not collected as part of the company registration process and is not available from the IDBR. In addition the IDBR does not cover the whole economy as many small 'micro' businesses do not need to register for VAT or PAYE.

Map 2.10

The map showing rates of female self-employment for the UK has been constructed mainly from unitary and county level data. However, in order to provide greater reliability of the estimates some of the smaller counties/unitary authorities have been combined. Those that have been combined are listed in Table 2.25. Information for London is presented for Inner and Outer London. 


\section{Table 2.25 Combined authorities for presentation in Map 2.10}

\begin{tabular}{|c|c|}
\hline \multicolumn{2}{|c|}{ Combined upper tier authorities } \\
\hline North East & South East \\
\hline Durham and Northumberland & \multirow{2}{*}{$\begin{array}{l}\text { Bracknell Forest, West } \\
\text { Berkshire, Reading, Slough, } \\
\text { Windsor and Maidenhead and } \\
\text { Wokingham }\end{array}$} \\
\hline $\begin{array}{l}\text { Hartlepool, Middlesbrough, } \\
\text { Stockton-on-Tees and Redcar } \\
\text { and Cleveland }\end{array}$ & \\
\hline North West & $\begin{array}{l}\text { Buckinghamshire and Milton } \\
\text { Keynes }\end{array}$ \\
\hline Halton and Warrington & \multirow{2}{*}{$\begin{array}{l}\text { Hampshire, Portsmouth and } \\
\text { Southampton }\end{array}$} \\
\hline Lancashire, Blackburn with & \\
\hline Darwen and Blackpool & Kent and Medway \\
\hline Yorkshire and The Humber & South West \\
\hline $\begin{array}{l}\text { Kingston upon Hull, City of and } \\
\text { East Riding of Yorkshire }\end{array}$ & Dorset and Poole \\
\hline East Midlands & Wales \\
\hline $\begin{array}{l}\text { Derbyshire and Derby } \\
\text { Leicestershire, Leicester and }\end{array}$ & $\begin{array}{l}\text { Bridgend, Vale of Glamorgan, } \\
\text { Rhondda, Cynon, Taff and } \\
\text { Merthyr Tydfil }\end{array}$ \\
\hline $\begin{array}{l}\text { Rutland } \\
\text { Lincolnshire, North East }\end{array}$ & $\begin{array}{l}\text { Caerphilly, Blaenau Gwent, } \\
\text { Torfaen and Newport }\end{array}$ \\
\hline $\begin{array}{l}\text { Lincolnshire and North } \\
\text { Lincolnshire }\end{array}$ & Flintshire and Wrexham \\
\hline \multirow{2}{*}{$\begin{array}{l}\text { Nottinghamshire and } \\
\text { Nottingham }\end{array}$} & Swansea and Neath Port Talbot \\
\hline & Scotland \\
\hline West Midlands & \multirow{2}{*}{$\begin{array}{l}\text { Aberdeen City and } \\
\text { Aberdeenshire }\end{array}$} \\
\hline \multirow{2}{*}{$\begin{array}{l}\text { Shropshire and Telford and } \\
\text { Wrekin }\end{array}$} & \\
\hline & Clackmannanshire and Fife \\
\hline $\begin{array}{l}\text { Staffordshire and Stoke-on- } \\
\text { Trent }\end{array}$ & $\begin{array}{l}\text { East Ayrshire and South } \\
\text { Lanarkshire }\end{array}$ \\
\hline East & East Lothian and Midlot \\
\hline Bedfordshire and Luton & \multirow{2}{*}{$\begin{array}{l}\text { East Renfrewshire and } \\
\text { Renfrewshire }\end{array}$} \\
\hline Cambridgeshire and & \\
\hline Peterborough & \multirow{2}{*}{$\begin{array}{l}\text { Falkirk, West Lothian and North } \\
\text { Lanarkshire }\end{array}$} \\
\hline \multirow[t]{3}{*}{ Essex and Thurrock } & \\
\hline & $\begin{array}{l}\text { North Ayrshire and South } \\
\text { Ayrshire }\end{array}$ \\
\hline & $\begin{array}{l}\text { West Dunbartonshire, East } \\
\text { Dunbartonshire and Inverclyde }\end{array}$ \\
\hline
\end{tabular}

\section{Notes on sources}

\section{Labour Force Survey and Annual Population Survey}

The Labour Force Survey (LFS) is a quarterly survey carried out by the Office for National Statistics (ONS) and resultant datasets are combined and boosted by an annual sample to produce the Annual Population Survey (APS) data. The sample size of these two surveys is sufficient to provide reliable data disaggregated by sex and location. Whilst the LFS cannot directly measure the number of female owned businesses, as it measures people rather than any businesses/enterprises they may own, it provides a breadth of information about the activities of both males and females in the work-place. The data extends beyond the usual employment and self-employment rates and levels and can be used to specifically measure the number of business owners.
The LFS is a survey of households throughout the UK; it contains information about the sex and ethnicity of each person surveyed. As would be expected of a labour force survey, it also contains information on the economic activity of each person, including whether they work for themselves, what industry they work in, the hours they work and the size of the company they work for. People who are self-employed are often used as a proxy for business ownership, as these numbers are much easier and more frequently estimated.

The LFS has better coverage of the number of soleproprietors and those working in partnerships, but its coverage of the total number of companies is inferior to that of the IDBR. These are both reasonable assumptions to make as:

1. not all small businesses need to register for VAT or PAYE and

2. not all business owners appear on the LFS, only business owners active in the labour market are identifiable from the LFS.

The Labour Force Survey User Guide

www.statistics.gov.uk/StatBase/Product.asp?vInk=1537\&

Pos $=\&$ ColRank $=1 \&$ Rank $=272$

gives access to various volumes:

Vol 1: Background and methodology

Vol 2: LFS questionnaire

Vol 2a: Transitional questionnaire

Vol 3: Details of LFS variables

Vol 3: Details of LFS variables (1992-2002)

Vol 4: LFS standard derived variables

Vol 5: LFS classifications

Vol 6: LFS local area data

Vol 7: LFS variables 1979-91

Vol 8: Household and family data

Vol 9: Eurostat and Eurostat derived variables

Information about the Annual Population Survey can be found at:

www.statistics.gov.uk/downloads/theme_population/ Annual_Population_Survey.pdf

Strengths and Weaknesses of LFS self-employment data

Self-employment is often used as a proxy for business ownership, and in many ways it is suited to this purpose, however it is important to be aware of both the strength and limitations in using self-employment in this way.

The LFS offers the potential to measure changes in business ownership on a quarterly basis through using selfemployment or using a more specific estimate of business ownership when available or through combining existing variables together. The principle use of the Labour Force Survey is the measurement of employment trends across the 
UK and the main components of the data are published on a monthly basis with microdata published on a quarterly basis.

The Annual Population Survey (APS) is an annual version of the LFS and uses data from the LFS alongside several boost surveys to provide more precise estimates for lower geographic levels. Typically the APS has a sample size three times as large as the quarterly LFS. This means that whereas the threshold of reliability for a figure from the LFS is about 10,000 the APS is reliable for some estimates as small as 2,000 . Values from overlapping time periods of the LFS/APS should not be compared or used to determine change.

Self-employment is measured using the LFS/APS; these are surveys of people living in private households. As such the measure of self-employment is an estimate and subject to sampling variability. For example even in the South East, which has the highest number of self-employed females and therefore lower variability, the range (confidence interval) is $+/-13,000$. So if the number of self-employed was estimated at 200,000 we would be 95 per cent confident that the true level of self-employment was between 183,000 and 217,000 . Table 2.26 gives details of the confidence intervals for other regions.

Respondents classify their own economic activity. Prior to the 2003 re-weighting exercise this was not the case; the LFS operated the Census matrix edit, this reclassified certain self-employed people to employees based on the nature of their occupation. The rationale for this was that certain occupations cannot be carried out as selfemployment.

Aside from providing a means of measuring the number of self-employed/business owners and the types of activity that they undertake, the LFS also provides an opportunity to

\section{Table 2.26 Female self-employment} confidence intervals ( $\mathrm{CI})$

\begin{tabular}{lrrrr} 
& \multicolumn{1}{c}{$\begin{array}{l}\text { Self- } \\
\text { employment }\end{array}$} & \multicolumn{3}{c}{$\begin{array}{l}\text { Self- } \\
\text { employment } \\
\text { rate }(16+)\end{array}$} \\
\cline { 2 - 5 } North East & 30,000 & 4,000 & $2.8 \%$ & $0.4 \%$ \\
North West & 101,000 & 8,000 & $3.6 \%$ & $0.3 \%$ \\
Yorkshire and & 85,000 & 8,000 & $4.0 \%$ & $0.4 \%$ \\
The Humber & 79,000 & 9,000 & $4.4 \%$ & $0.5 \%$ \\
East Midlands & 76,000 & 8,000 & $3.5 \%$ & $0.3 \%$ \\
West Midlands & 120,000 & 11,000 & $5.2 \%$ & $0.5 \%$ \\
East & 182,000 & 14,000 & $5.9 \%$ & $0.4 \%$ \\
London & 215,000 & 13,000 & $6.3 \%$ & $0.4 \%$ \\
South East & 135,000 & 10,000 & $6.2 \%$ & $0.5 \%$ \\
South West & 51,000 & 4,000 & $4.1 \%$ & $0.3 \%$ \\
Wales & 88,000 & 6,000 & $4.0 \%$ & $0.3 \%$ \\
Scotland & 25,000 & 5,000 & $3.5 \%$ & $0.7 \%$ \\
Northern Ireland & $1,184,000$ & 28,000 & $4.7 \%$ & $0.1 \%$ \\
United Kingdom & & & & \\
\hline
\end{tabular}

Source: Annual Population Survey, Office for National Statistics investigate the ways in which a number of demographic factors impact on self-employment. For example, why people choose to become self-employed or how they work. Some of these questions can be used to cross-check the information gathered and therefore can quality assure the level of self-employment. These suggest that while the 'real' level of self-employment is slightly lower than LFS/APS estimates, the difference between the real level and the LFS/ APS estimate is mainly due to employee business owners being incorrectly coded as self-employed.

A key feature of the LFS is that it is a panel survey, meaning that respondents are contacted on more than one occasion (in the LFS respondents are contacted five times at quarterly intervals). One of the outputs from the survey is a selection of longitudinal files where answers from consecutive quarters are presented together allowing changing employment circumstances to be monitored. An added benefit of the LFS being a panel survey is that estimates of change are more precise than for an equivalent survey with independent quarterly samples. This means that the LFS is especially suited to measuring the change in selfemployment over time.

\section{Business demography data}

This is a new release from the Office for National Statistics (ONS) giving details of business start-ups and failures. This series replaces data relating to VAT registrations formerly published by BERR. A summary of the differences www.statistics.gov.uk/elmr/12_08/downaloads/ELMR_ Dec08_Allen.pdf

Data can be found at: www.statistics.gov.uk/downloads/ theme_commerce/Business-Demography-2007.xls

\section{Further information}

NOMIS $^{\circledR}$ contains data on population and the labour market at various geographical levels: www.nomisweb.co.uk

Enterprise Directorate (formerly Small Business Service), Department for Business, Enterprise and Regulatory Reform (BERR) have also conducted household enterprise surveys and there have been several academically focussed research projects undertaken on this subject.

www.berr.gov.uk/bbf/enterprise-smes/index.html

Regional Economic Development documents www.berr.gov.uk/regional/index.html

The Global Enterpriseship Monitor (GEM) research consortia, led in the UK by the London Business School, estimates activity across 42 countries and their reports provide an overview of entrepreneurial activity for both men and women. Report for 2007:

www.london.edu/assets/documents/PDF/GEM_UK_2007_ Report.pdf 
Or from the GEM Consortium site:

www.gemconsortium.org/document. aspx?id=689

The following regional summaries are also available in respect of the 2007 GEM survey:

\section{Regional report:}

\begin{tabular}{|c|c|}
\hline North East & $\begin{array}{l}\text { www.gemconsortium.org/document. } \\
\text { aspx?id=571 }\end{array}$ \\
\hline North West & $\begin{array}{l}\text { www.gemconsortium.org/document. } \\
\text { aspx?id=572 }\end{array}$ \\
\hline Yorkshire and The Humber & $\begin{array}{l}\text { www.gemconsortium.org/document. } \\
\text { aspx?id=578 }\end{array}$ \\
\hline East Midlands & $\begin{array}{l}\text { www.gemconsortium.org/document. } \\
\text { aspx?id=566 }\end{array}$ \\
\hline West Midlands & $\begin{array}{l}\text { www.gemconsortium.org/document } \\
\text { aspx?id=577 }\end{array}$ \\
\hline East & $\begin{array}{l}\text { www.gemconsortium.org/document. } \\
\text { aspx?id=567 }\end{array}$ \\
\hline South East & $\begin{array}{l}\text { www.gemconsortium.org/document. } \\
\text { aspx?id=575 }\end{array}$ \\
\hline Scotland & $\begin{array}{l}\text { www.gemconsortium.org/document. } \\
\text { aspx?id=573 }\end{array}$ \\
\hline Northern Ireland & $\begin{array}{l}\text { www.gemconsortium.org/document. } \\
\text { aspx?id=570 }\end{array}$ \\
\hline
\end{tabular}

\section{References}

'The introduction of additional questions on employment status to the Labour Force Survey', Hill R in Labour Market Trends, Dec 2000.

'Owner managers in the Labour Force Survey', Laux R \& Dellow M in Labour Market Trends, June 1999

'Comparison of statistics on jobs: September 2007', Machin, A in Economic and Labour Market Review, March 2008 www.statistics.gov.uk/cci/article. asp? $i d=1950$

Guide to the Labour Market:

www.statistics.gov.uk/about/data/guides/LabourMarket/

The Regional State of Womens' Enterprise in the English regions:

www.prowess.org.uk/documents/

TheStateof WomensEnglandintheEnglishRegionsthisis theoneto distribute.pdf

State of Women's Enterprise in the UK, Dr. Rebecca Harding www.prowess.org.uk/documents/

StateofWomensenterpriseintheukfinal.pdf

Women's Business Ownership: research and policy executive summary:

www.dti.gov.uk/files/file38338.pdf
Womens' enterprise task force:

www.womensenterprise.co.uk/stats_wetf.asp

Shaping a fairer future - executive summary, The Women and Equality Unit:

www.womenandequalityunit.gov.uk/publications/wwc_ shapingfairerfut_execsum06.pdf

\section{Regional Economic Strategies}

Regional Economic Strategies universally comment on 'developing a culture of enterprise' among all groups and specifically champion the improvement of female business enterprise and stronger promotion of enterprise to women. This ranges from ensuring that appropriate business support is targeted at women, including accessibility of finance to pledging effective action on issues regarding the lack of suitable and affordable child care to facilitate narrowing disparities. Phrases such as 'improve enterprise performance amongst women'; 'improving performance where there is untapped potential for entrepreneurship such as amongst women' and 'by inspiring women and providing positive role models, a large number of new businesses could be created'.

Some development agencies have set challenging targets 'to increase the proportion of women-owned enterprises' and various partnerships have been initiated to spearhead this. In the South East a specific target of increasing by 10,000 the number of female owned business by 2010 has been articulated as well as to improve the representation of females in the workplace.

North East www.onenortheast.com/page/res.cfm

North West www.nwda.co.uk/publications/strategy/ regional-economic-strategy-200.aspx

Yorkshire and The Humber www.yorkshire-forward.com/ about/what-we-do/strategy/the-res

East Midlands www.emda.org.uk/res/default.asp

West Midlands www.advantagewm.co.uk/Images/WMES_ tcm9-9538.pdf

East www.eeda.org.uk/res.asp

London www.lda.gov.uk/server.php?show= onWebDoc.446

South East www.seeda.co.uk/res/RES_2006-2016/ index.asp

South West www.southwestrda.org.uk/downloads/ document.asp?lang=\&documentid=1036\& 